\title{
A High Gain Super Wideband Metamaterial Based Antenna
}

\author{
Ishita Aggarwal (1), Sujata Pandey (1) and Malay Ranjan Tripathy \\ Department of Electronics and Communication Engineering, Amity School of Engineering and Technology, \\ Amity University Uttar Pradesh, Uttar Pradesh, Noida, India \\ iaggarwal1988@gmail.com, spandey@amity.edu,mrtripathy@amity.edu
}

\begin{abstract}
The paper proposes a high gain, metamaterial based super wideband (SWB) antenna. The SWB antenna has two inverted $U$ slots which are responsible for two notches at $3.5 \mathrm{GHz}$ and $5.5 \mathrm{GHz}$ frequencies. A flower-shaped slot is etched from the radiator to obtain the SWB characteristics. The super wideband antenna has dimensions of $30 \times 35 \times 1.5 \mathrm{~mm}^{3}$ with FR4 substrate. The antenna has a frequency bandwidth of $3.1 \mathrm{GHz}-15 \mathrm{GHz}$ for S11 <-10dB. A metamaterial unit cell is designed and simulated for permittivity and permeability characteristics. This shows a negative refractive index in the band of $2.4 \mathrm{GHz}$ to $8 \mathrm{GHz}$ and $8.2 \mathrm{GHz}$ to 9 GHz. A $3 \times 3$ array of metamaterial cells is used as a superstrate for the improvement of the gain characteristics. The fabricated prototype SWB antenna with superstrate has measured frequency bandwidth 3.1-15 GHz with notched bands at $3.5 \mathrm{GHz}$ and $5.5 \mathrm{GHz}$. The experimental and simulated results are in line with each other.
\end{abstract}

Index Terms - Gain, Metamaterial, Notched band, Super wideband antenna

\section{INTRODUCTION}

High data rate and wideband communication are gaining a ton of attention nowadays. The frequency ranging from 3.1-10.6 GHz was allocated by the FCC for UWB communication in the year 2002[1]. The SWB (Super Wideband) antennas provide benefit of low complexity, less costly, low interference, and high data rate [2]-[6]. Planar monopole antennas are designed to achieve these characteristics.

Electromagnetic interference is a serious problem as there are many other band services that occupy frequency bands within the ultrawideband bandwidth. The bands like WiMAX, WLAN, and ARN have frequency bands within this bandwidth. The intrinsic filters are introduced in the antenna at the desired service frequencies. There are several methods by which notching can be achieved, such as Ushaped, I-shaped, C- shaped or H-shaped slots are created inside the radiator to reduce interference [7]-[24]. Complementary Split Ring resonators (CSRR) are also used to dismiss the undesirable frequency band.

Metamaterials are artificial electromagnetic materials which consist of periodically arranged components. They have the property of negative permeability and permittivity. They are also called double negative materials. This property depends completely on the structure of the metamaterial [25]-[27]. In 1999, Smith discovered a new type of metamaterial which showed simultaneous negative 
permeability and permittivity. Over the last few years, metamaterial unit cells are embedded in antenna design and it has resulted in improving the performance and efficiency of the antenna. The metamaterial superstrate when mounted above the patch at a distance ranging from $\lambda / 4$ to $\lambda / 2$, there has been an increment in the gain of antenna and radiation efficiency. A Volkswagen Logo based design is created to give a UWB, miniaturization is achieved by loading metamaterial at the ground [28]. An ultrawideband antenna with three notches has been reported which showed improved characteristics using metamaterial [29]. Various metamaterial based structures like EBG and AMC, are used to get the improvement in gain characteristics of the antenna [30]-[32].

A high gain, super wideband antenna integrated with metamaterial superstrate, having two notched bands is proposed. Two inverted U-shaped slots are cut through the radiator on the upper side to dismiss WiMax and WLAN, whose dimensions are half the guided wavelength. The dimensions and positions are decided according to the required band notch filter. A novel I shaped split ring resonator (Metamaterial unit cell) has been proposed. The S parameters of metamaterial are extracted by using the equations presented in [26]. This superstrate layer is placed above the substrate at a distance of $\lambda$ $/ 3$ above the ground. The bandwidth of the antenna 3.1-15 GHz with a peak gain of $12 \mathrm{~dB}$ is obtained. The antenna is novel in terms of the flower shaped slotted design and high gain efficient metamaterial, as compared with other antennas designed in this range. Further the results of the simulated and fabricated antenna are compared and are found in good cognizance.

\section{ANTENNA THEORY AND DESIGN}

\section{A. Theoretical Background}

A high gain, wide bandwidth antenna has been designed in this paper. The proposed antenna comprises two parts: one is the SWB antenna and the other is the metamaterial superstrate. The Ray tracing model of the metamaterial SWB antenna has been shown in Fig. 1.A single metamaterial slab is placed above the antenna. The ground plane is placed beneath the antenna which does not allow backward radiations to propagate. The ground plane and the superstrate are behaving as a parallel plate capacitor. Multiple number of reflections occur between them. Resonance can be seen, when radiated and reflected waves are in phase, after a single round trip. A phase shift is introduced by the path length, total reflection on ground plane and by phase of reflection coefficient of partial reflective surface (PRS). The power is given the following equation [33-35]

$$
P=\frac{\left(1-R^{2}\right)}{1+R^{2}-2 R \cos \left[\Phi_{1}+\Phi_{2}-\left(\frac{4 \pi}{\lambda}\right) h \cos \theta\right]} F^{2}(\theta)
$$

Where, $P$ is total power, $R$ is the reflection coefficient, $\lambda$ is the free-space wavelength, $F(\theta)$ is the radiation pattern of the primary antenna, $h$ is the distance between the PRS and the ground plane and $\Phi_{1}$ and $\Phi_{2}$ are the path differences. 


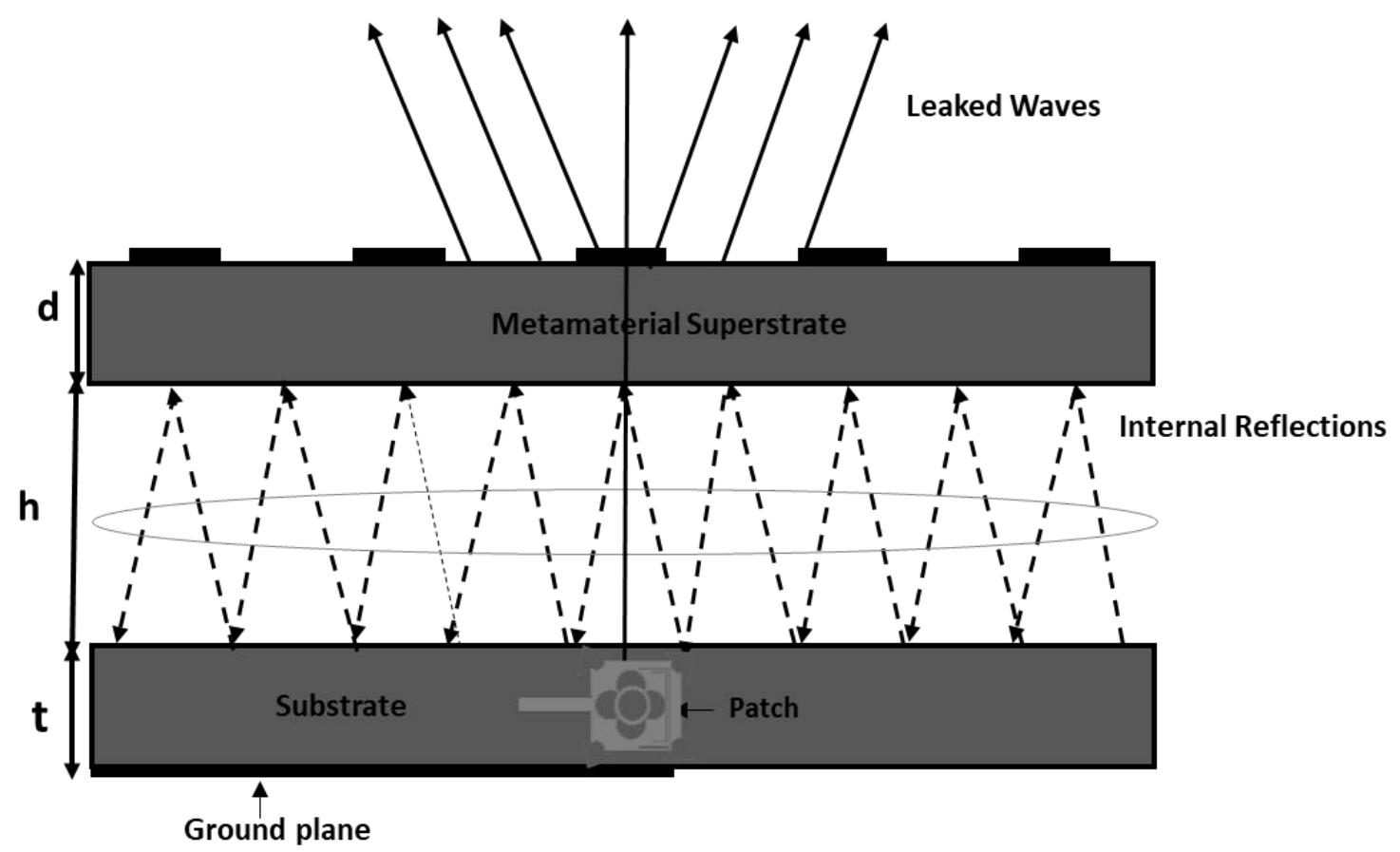

Fig. 1. Ray tracing model of proposed antenna.

The proposed metamaterial has a negative reflection phase, meets the condition of the resonance cavity. Fig. 2 shows the phase diagram of $S_{21}$ and $S_{11}$ of the proposed unit cell. There is a multiple reflection which occur inside the cavity leading to an increase in the gain at the direction of boresight $\left(\theta=0^{0}\right)$.

$$
P=\frac{\left(1-R^{2}\right)}{1+R^{2}-2 R \cos \left[\Phi_{1}+\Phi_{2}-\left(\frac{4 \pi}{\lambda}\right) h\right]} F^{2}(0)
$$

when

$$
\cos \left[\Phi_{1}+\Phi_{2}-\left(\frac{4 \pi}{\lambda}\right) h\right]
$$

The fabry-perot cavity resonance distance condition is given by:

$$
h=\left(\Phi_{\text {Superstarte }}+\Phi_{\text {Ground }}\right) \frac{\lambda}{4 \pi} \pm N \frac{\lambda}{2}
$$

The maximum power in direction of boresight angle $\theta=0$ is given by

$$
\begin{gathered}
P=\frac{\left(1-R^{2}\right)}{(1-R)^{2}} F^{2}(0) \\
P_{\text {Max }}=\frac{(1+R)}{1-R} P_{\text {min }}
\end{gathered}
$$


Where, $\Phi_{\text {supertsrate }}$ is the reflection phase of the metamaterial superstrate, $\Phi_{\text {Ground }}$ is the reflection phase due to the ground plane, $\mathrm{h}$ is the distance between the ground plane and the metamaterial superstrate, $\mathrm{N}$ is an integer value such as $1,2,3 \ldots, \mathrm{n}=3.14, \lambda$ is the wavelength of the designed antenna, $\mathrm{t}$ is the thickness of the substrate, and $d$ is the thickness of the superstrate, $G$ is the boresight gain, and $R$ is the reflection coefficient. The antenna device with a metamaterial superstrate will achieve high directivity and gain at the resonant distance $h$.

The maximum broadside gain in terms of efficiency is given by

$$
G=\left(\frac{4 \pi}{\lambda_{0}^{2}}\right) A_{e f f} \cdot E_{f}
$$

Where $A_{\text {eff }}$ is the effective aperture size, $G$ is the maximum gain, value of $n$ is $3.14, E_{f}$ is the radiation

efficiency, $\lambda_{0}$ is the wavelength of antenna.

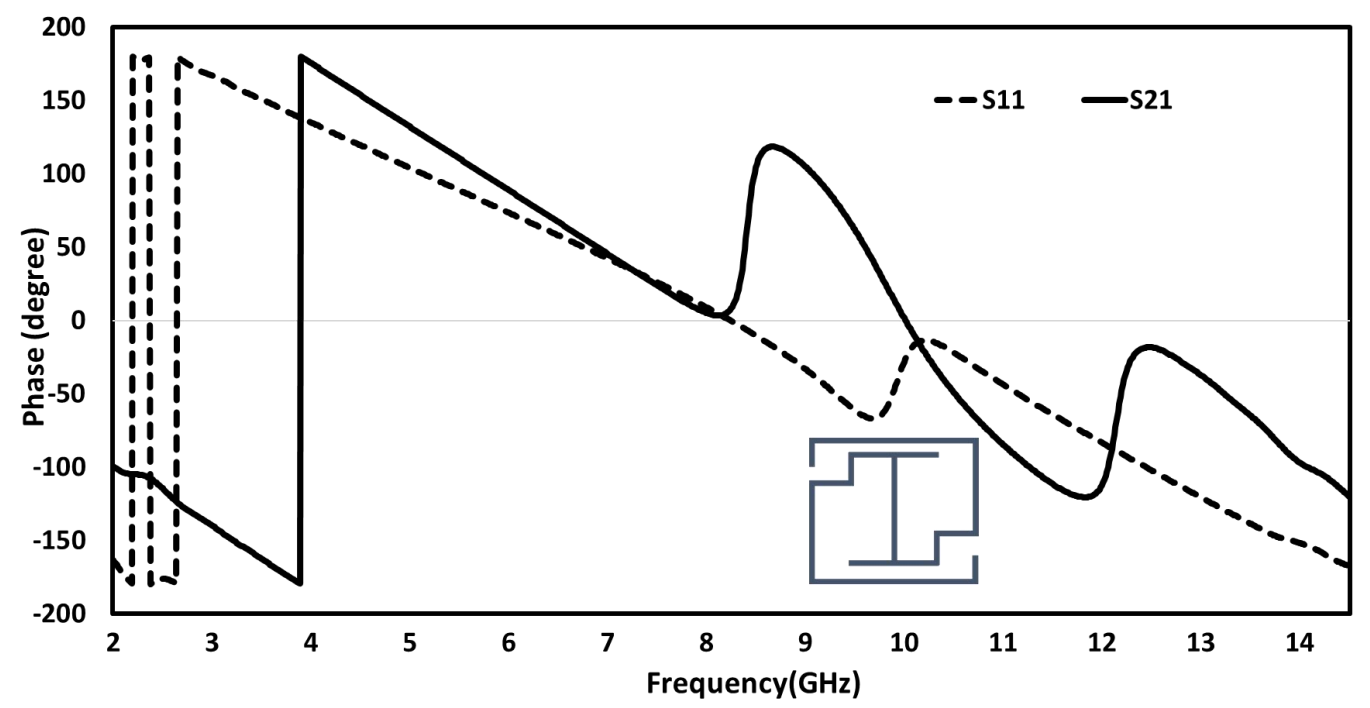

Fig. 2. Phase diagram of metamaterial unit cell.

The design of the proposed metamaterial structure with the analysis is explained below.

\section{B. Structure and Characteristics of Metamaterial unit cell}

Metamaterials provide electromagnetic properties that aren't available in nature, which can help in boosting the gain of a microstrip antenna. The metamaterial unit cell works as a foundational block for the antenna superstrate. The metal lines with a thickness of $0.035 \mathrm{~mm}$ are printed on a $1.5 \mathrm{~mm}$ thick FR4 substrate with relative permittivity of 4.4. Fig. 3 depicts the proposed I-shaped metamaterial unit cell, simulation set up, and the equivalent structure. The dimensions of I shaped split ring is $8 \times 8 \times 1.5 \mathrm{~mm}^{3}$. The I shaped structure and the outside loop produce inductance and the gap between the loop produces capacitance. Table I shows the design specification of the unit cell used here. The E field is uniformly applied in $\mathrm{x}$ direction, and the $\mathrm{H}$ field is uniformly applied in $\mathrm{y}$ direction. The wave ports are applied across $\mathrm{z}$ direction. The direction of the wave is from $+\mathrm{z}$ 
direction to -z direction.

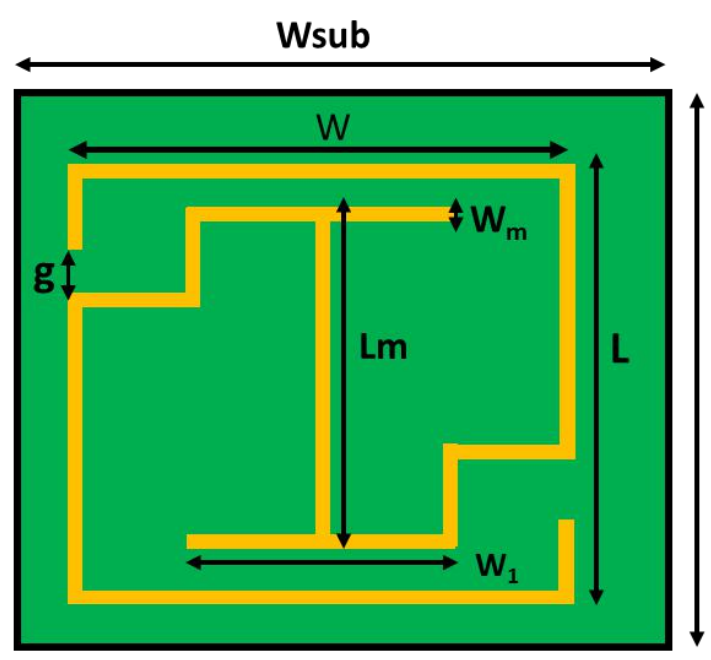

(a)

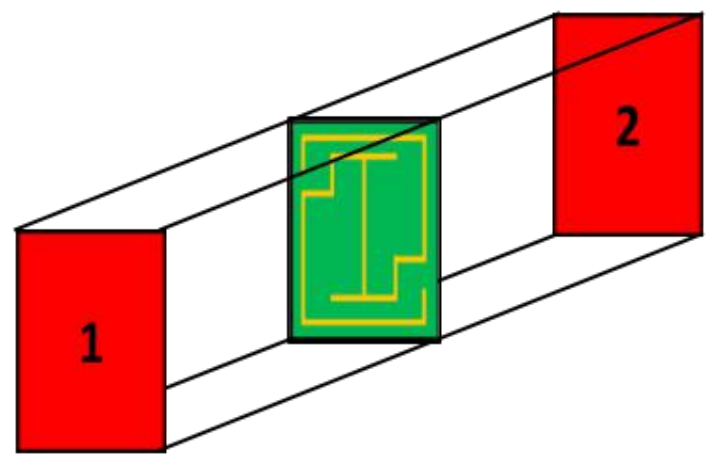

(b)

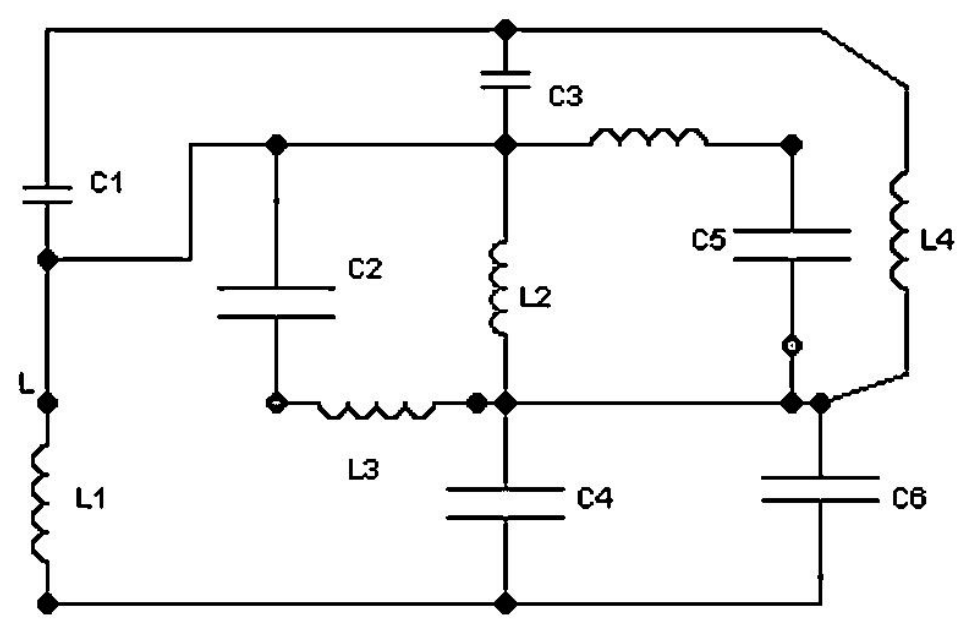

(c)

Fig. 3. (a) Proposed geometry of unit cell, (b) Simulation of metamaterial unit cell, (c) Equivalent structure of metamaterial unit cell.

TABLE I. OPTIMIZED DIMENSIONS OF METAMATERIAL

\begin{tabular}{cccc}
\hline Parameters & Dimensions & Parameters & Dimensions \\
\hline $\mathrm{L}_{\text {sub }}$ & $10 \mathrm{~mm}$ & $\mathrm{~W}_{\text {sub }}$ & $10 \mathrm{~mm}$ \\
$\mathrm{~h}_{\text {sub }}$ & $1.5 \mathrm{~mm}$ & Copper height & $0.035 \mathrm{~mm}$ \\
$\mathrm{Gap}$ & $0.5 \mathrm{~mm}$ & $\mathrm{~W}_{\mathrm{m}}$ & $0.5 \mathrm{~mm}$ \\
$\mathrm{~W}$ & $8 \mathrm{~mm}$ & $\mathrm{~L}$ & $8 \mathrm{~mm}$ \\
$\mathrm{~W}_{\mathrm{l}}$ & $4 \mathrm{~mm}$ & $\mathrm{~g}$ & $0.5 \mathrm{~mm}$ \\
Metal strip width & $0.5 \mathrm{~mm}$ & $\mathrm{Lm}$ & $6 \mathrm{~mm}$
\end{tabular}

The magnitude and phase of the simulated Reflection and Transmission coefficients are displayed in Fig. 4 (a) and Fig. 4 (b). 


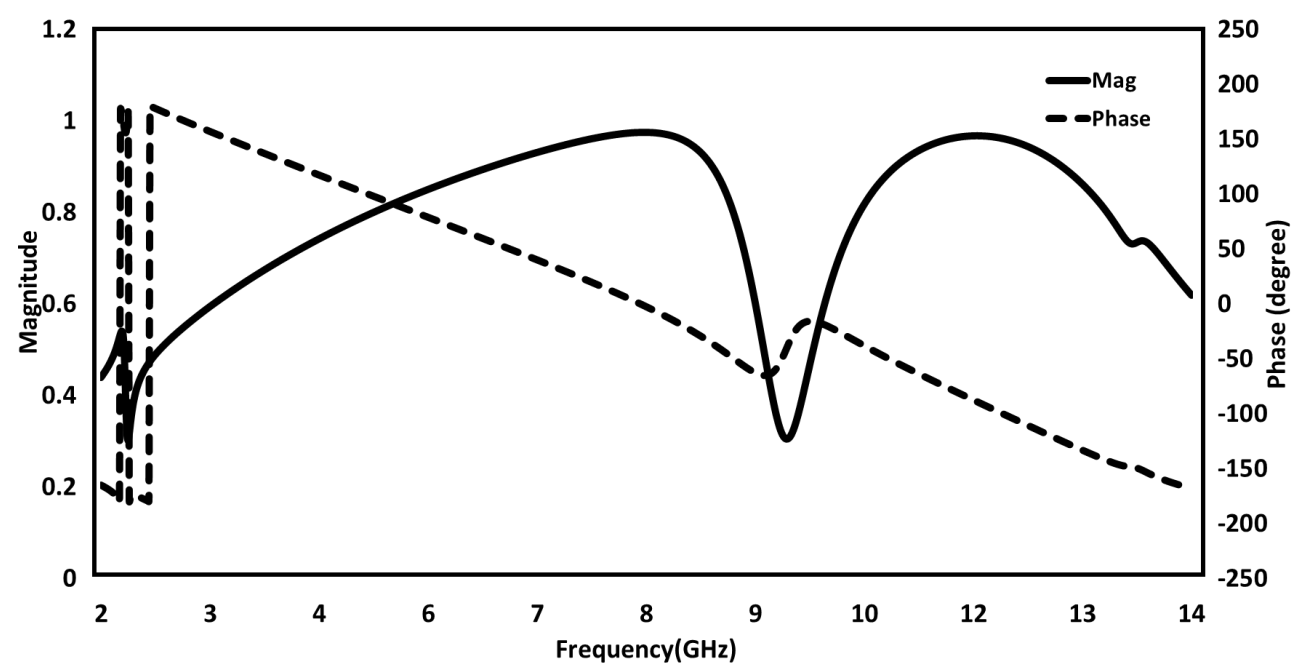

(a)

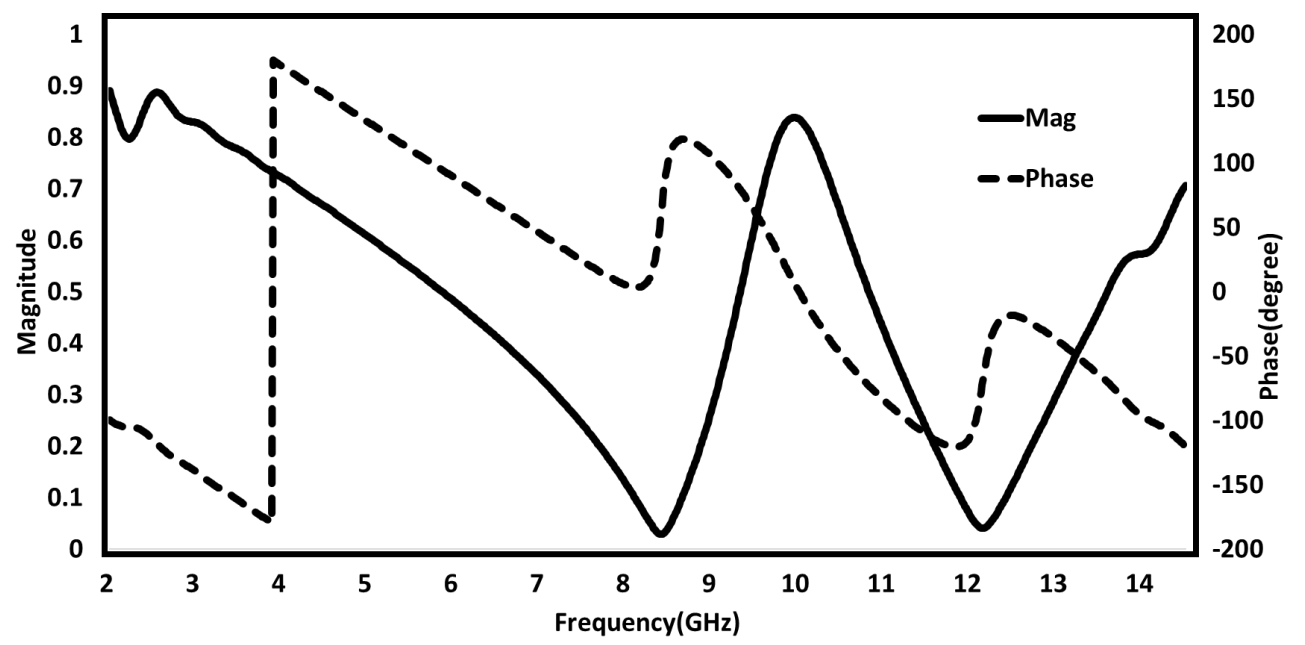

(b)

Fig. 4. (a) Magnitude and Phase of the Reflection coefficient, (b) Magnitude and Phase of the Transmission coefficient.

The properties of metamaterial are extracted from simulated S11 and S21 using the Nicolson-RossWeir (NRW) technique. The equations given below have been used to achieve the permeability, permittivity, and refractive index of the unit cell using the following equations [26].

$$
\begin{aligned}
& S 11=\frac{\left(1-\boldsymbol{\Gamma}^{2}\right) Z}{1-\boldsymbol{\Gamma} Z^{2}} \\
& S 21=\frac{\left(1-Z^{2}\right) \boldsymbol{\Gamma}}{1-\boldsymbol{\Gamma}^{2} Z^{2}}
\end{aligned}
$$




$$
\begin{gathered}
z=\exp \left(-j\left(\frac{2 \pi f}{c}\right) \sqrt{\mathcal{E} r \mu r d}\right. \\
\mathcal{E} r=\frac{c}{j n f d} \frac{(1-\mathrm{S} 21-\mathrm{S} 11)}{(1+\mathrm{S} 21+\mathrm{S} 11)} \\
\mu_{r}=\frac{c}{j \pi f d} \frac{(1-\mathrm{S} 21+\mathrm{S} 11)}{(1+\mathrm{S} 21-\mathrm{S} 11)} \\
\eta_{r}=\frac{c}{j n f d} \sqrt{\frac{\left.(S 21-1)^{2}-S 11^{2}\right)}{\left(1+S 21^{2}\right)-S 11^{2}}}
\end{gathered}
$$

S11 is the reflection coefficient, S21 is the transmission coefficient is the relative permeability, $\varepsilon_{\mathrm{r}}$ is the relative permittivity, $d$ is the thickness of the substrate, $\eta_{r}$ is the relative refractive index and $z$ is the effective impedance, $\mathrm{c}$ is the speed of light, $\Gamma$ is the reflection coefficient, value of $\mathrm{n}$ is $3.14, \mathrm{f}$ is the frequency.

Fig. 5 (a) and (b) show the permittivity and permeability of metamaterial unit cells in range 2-14 GHz. Fig. 5(c) shows negative refractive in frequency band of $2.4 \mathrm{GHz}$ to $8 \mathrm{GHz}$ and $8.2 \mathrm{GHz}$ to 9 GHz. The permeability, permittivity, and refractive index are showing negative peaks. So, this material can be called a metamaterial. A slab of the meta-unit cells boosts the gain of the SWB antenna.

To find the significance of the design parameters, a parametric analysis is performed. Many simulations were performed by varying the thickness of the metamaterial unit cell and by varying the gap in the unit cell (i.e., split rings). This analysis helps in understanding the resonance frequency mechanism and the design technique used. The proposed metamaterial unit cell's parametric analysis is carried out by adjusting the thickness of the unit cell. The reflection coefficient and transmission of metamaterial are shown in Fig. 6(a) and 6(b) when the thickness of the metamaterial unit cell is varied between $0.5 \mathrm{~mm}$ and $0.8 \mathrm{~mm}$. When the outer ring width is $0.5 \mathrm{~mm}$, the resonance frequency is 8.2 GHz. At a width of $0.8 \mathrm{~mm}$, the resonance frequency is shifted to $9.2 \mathrm{GHz}$. This means that with the increase in the width the resonance frequency shifts towards a higher frequency.

The curve of the reflection coefficient shifts towards the right i.e., towards higher frequency when the width of metamaterial is increased. The resonance frequency decreases with a decrease in the width of the metamaterial unit cell. The resonance frequency of the metamaterial unit cell can easily be achieved by optimizing the width of the unit cell. The parametric analysis for the metamaterial is done in which the gap of the split rings is varied from 0.1 to $0.5 \mathrm{~mm}$. 


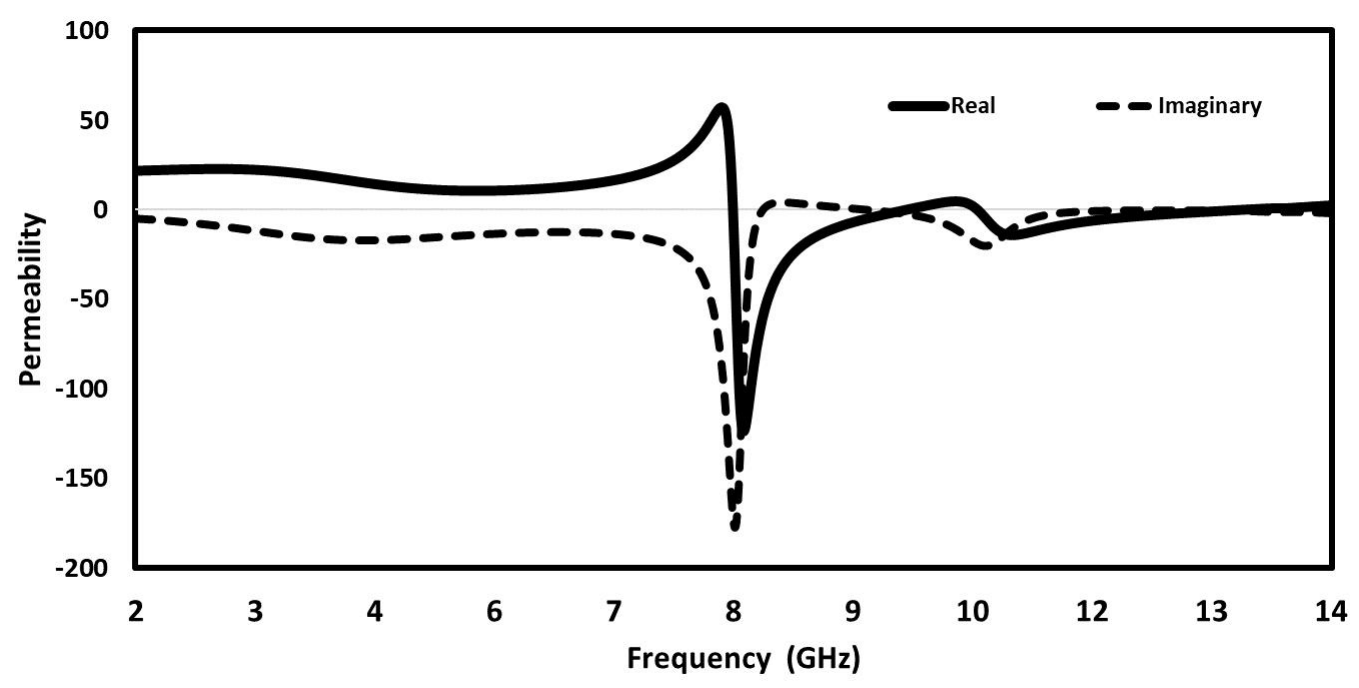

(a)

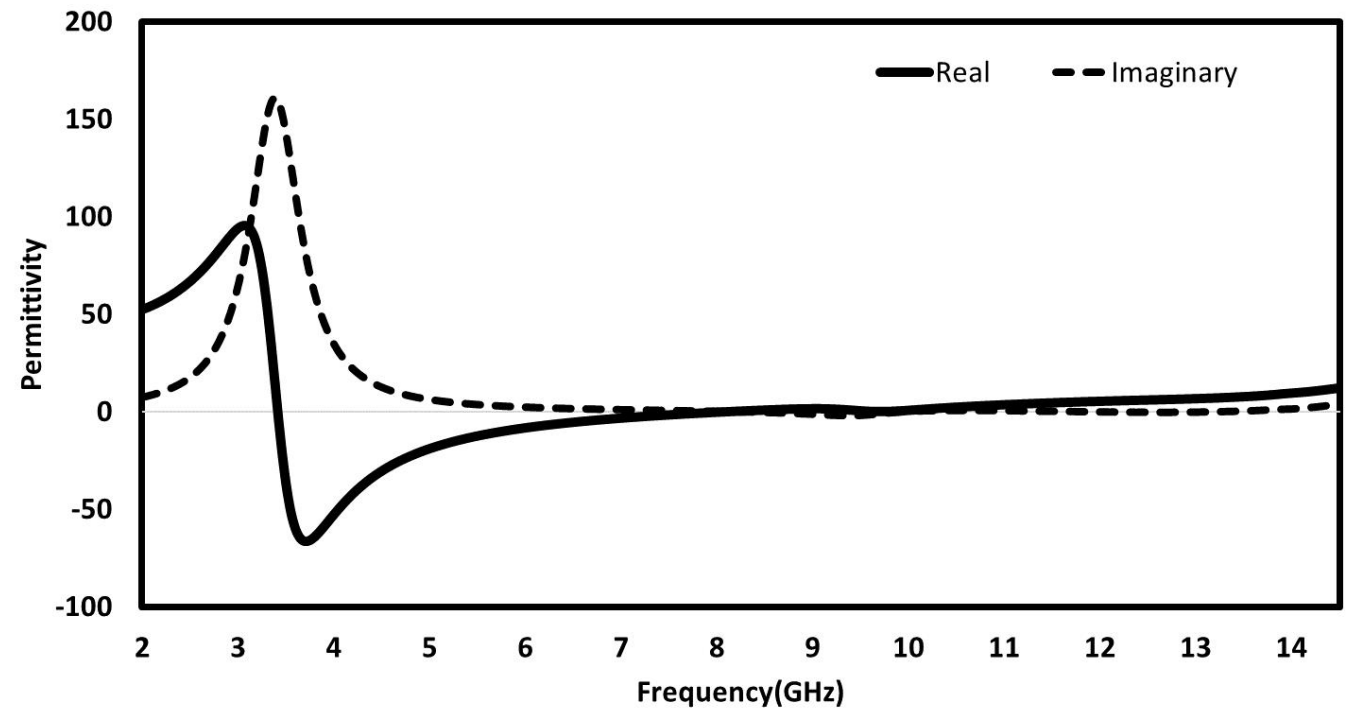

(b)

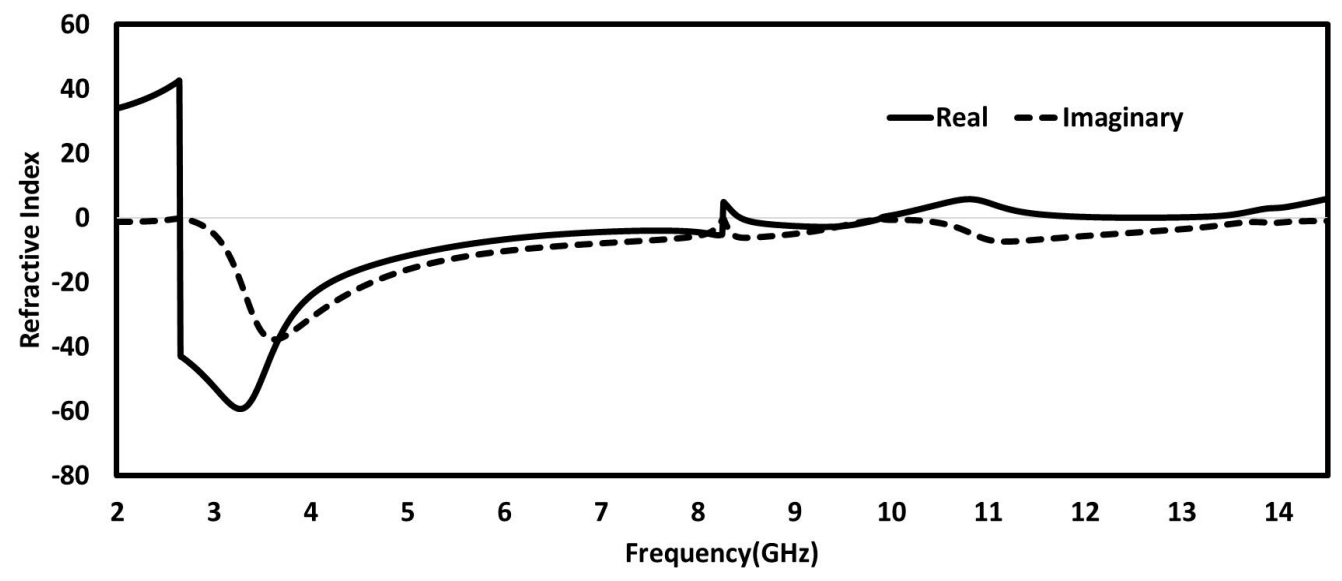

(c)

Fig. 5. (a) Relative Permeability vs Frequency, (b) Relative Permittivity vs Frequency, (c) Refractive index vs Frequency. 


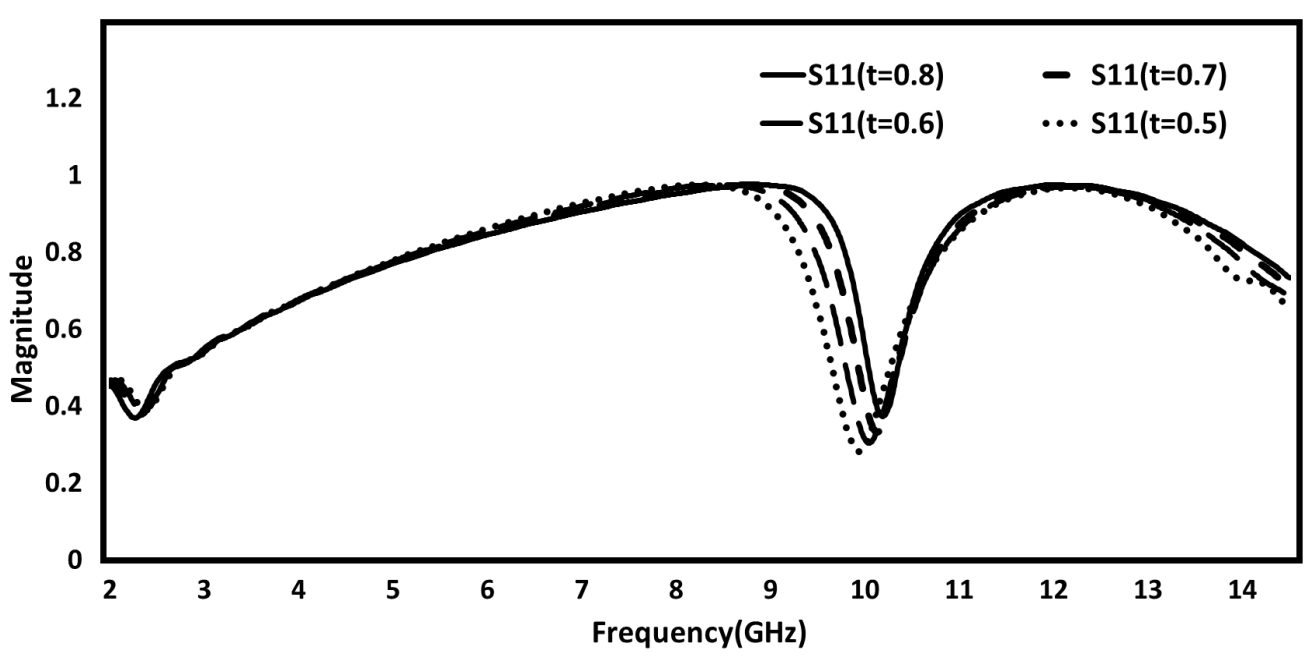

(a)

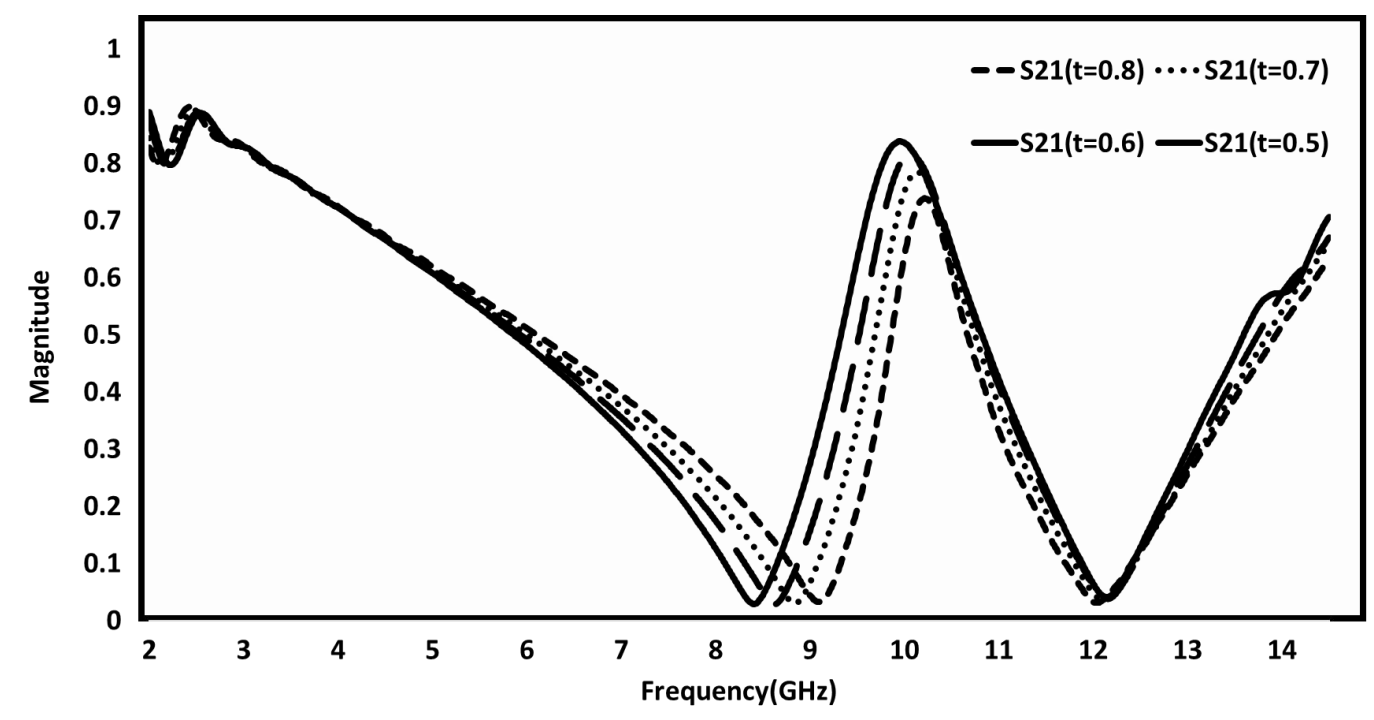

(b)

Fig. 6. (a) Magnitude of Reflection Coefficient, (b) Magnitude of Transmission Coefficient

The reflection coefficient and transmission coefficient are affected by increasing or decreasing the gap between the split rings. Fig. $7(\mathrm{a})$ and $7(\mathrm{~b})$ shows reflection coefficient and transmission coefficient with variation in the capacitive Gap $(\mathrm{g})$. With the increase in the gap, the resonance frequency increases and vice-versa. 


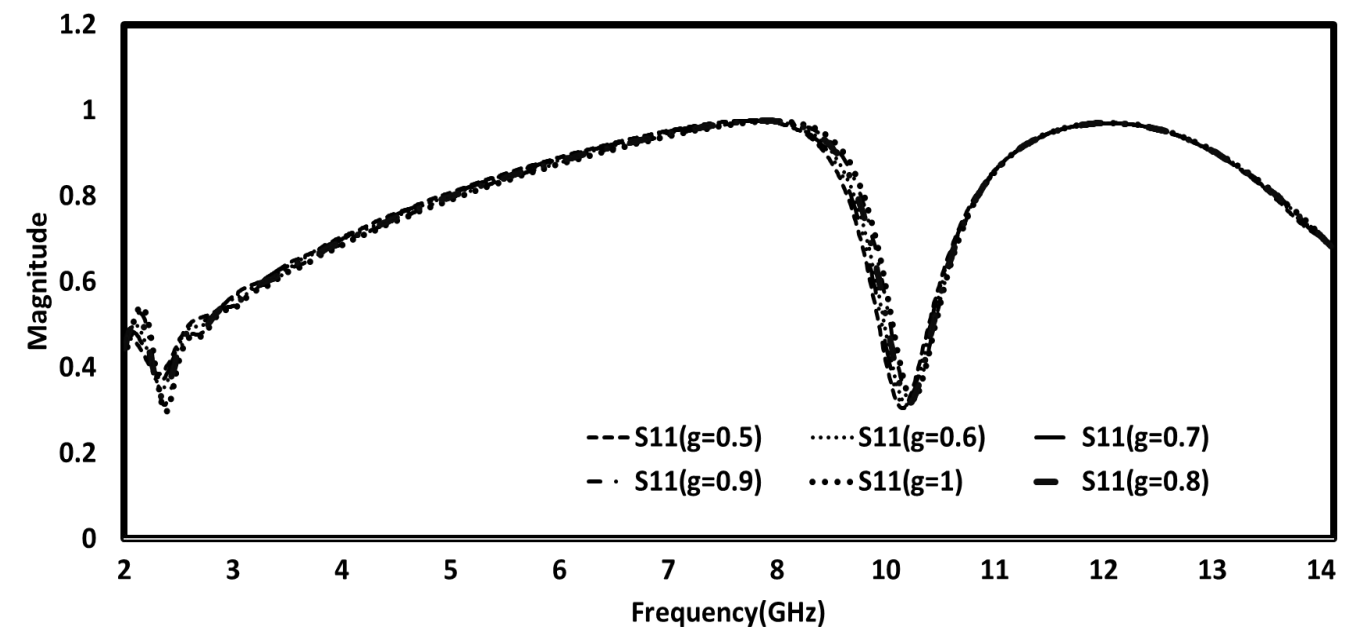

(a)

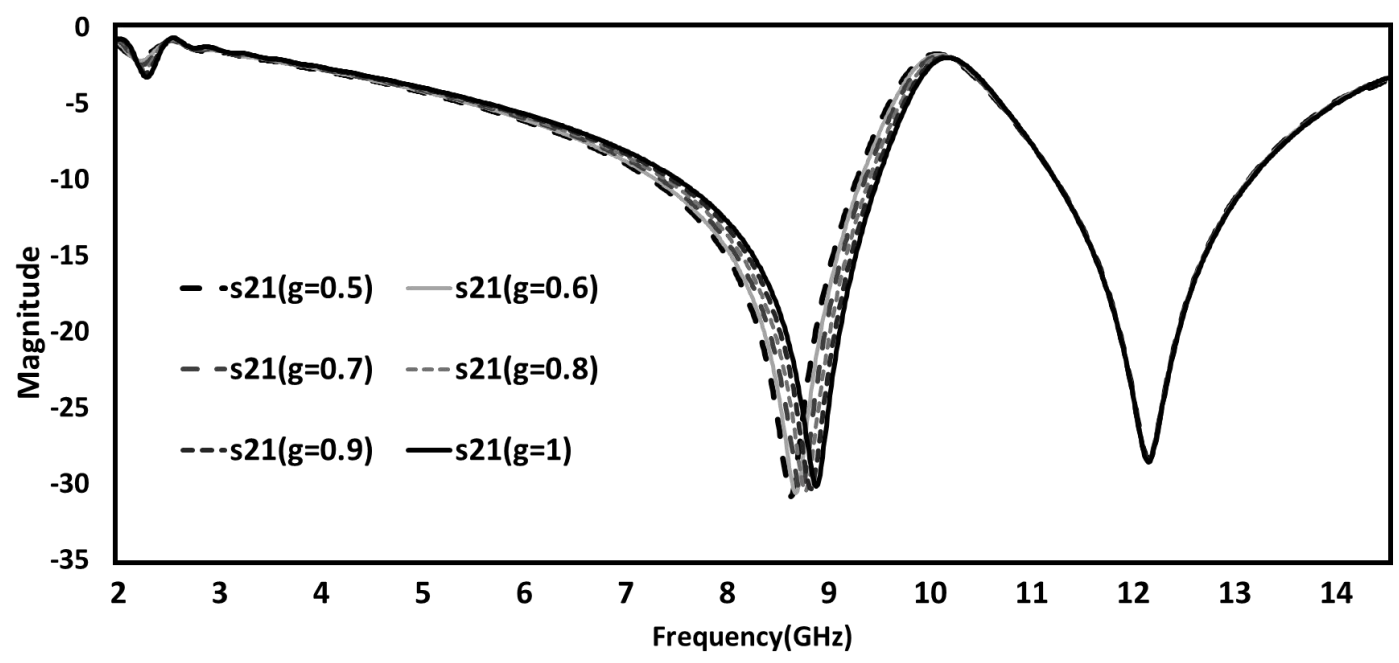

(b)

Fig. 7. (a) Magnitude of Reflection Coefficient, (b. Magnitude of Transmission coefficient.

\section{Design Methodology of Proposed Antenna}

The proposed antenna design is discussed step by step in this section. The designed antenna has two notches, with a rectangle-shaped radiating element. FR4 substrate is used as a base for printing antenna having a dielectric constant of 4.3 loss tangent 0.02 , and height $1.5 \mathrm{~mm}$. The design simulation is done using HFSS' 13 . The antenna has dimensions of $30 \times 35 \times 1.5 \mathrm{~mm}^{3}$. To get the notches at desired frequencies, two different size $U$ shaped slots are created in the radiator. The Antenna gain increases when an array of metamaterial superstrate is loaded at the top of the radiator. Fig. 8 shows the schematic diagram of the metamaterial based SWB along with its prototype. Table II optimized parameters of the proposed antenna. 


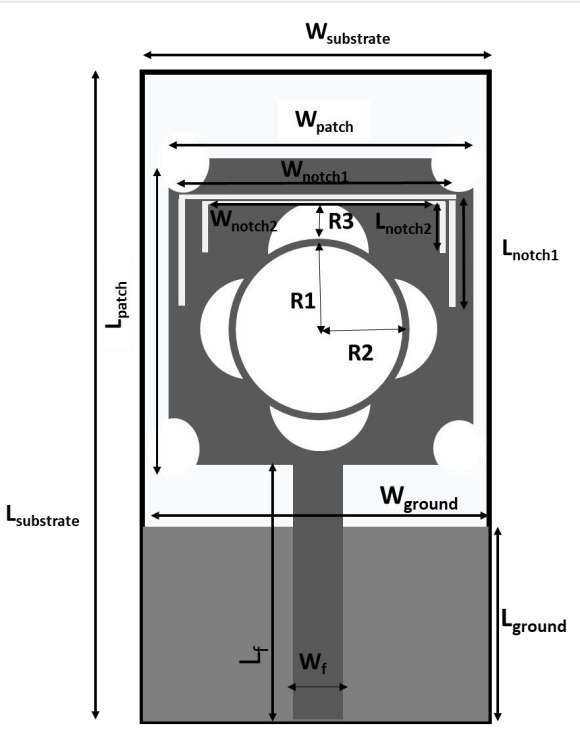

(a)

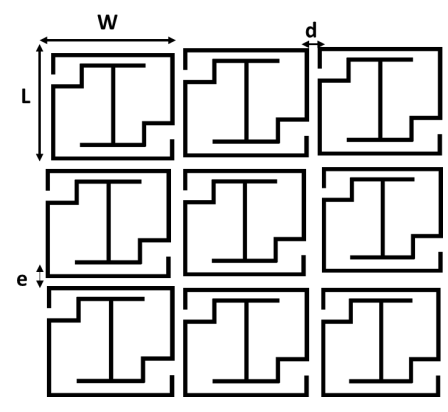

(b)

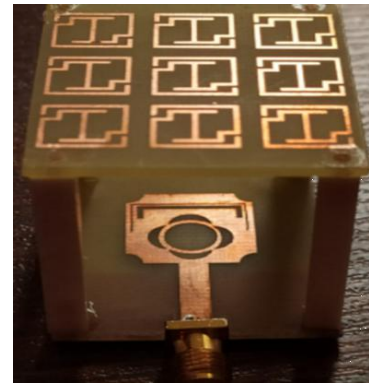

(c)

Fig. 8. (a) SWB antenna, (b) Top view of Proposed antenna, (c) Prototype of Proposed antenna.

TABLE II. OPTIMIZED DIMENSIONS OF PROPOSED ANTENNA

\begin{tabular}{cc}
\hline Parameter & Value \\
\hline $\mathrm{L}_{\text {substrate }}$ & $35 \mathrm{~mm}$ \\
$\mathrm{~W}_{\text {substrate }}$ & $30 \mathrm{~mm}$ \\
$\mathrm{~L}_{\text {patch }}$ & $15 \mathrm{~mm}$ \\
$\mathrm{~W}_{\text {patch }}$ & $14.5 \mathrm{~mm}$ \\
$\mathrm{~W}_{\text {ground }}$ & $30 \mathrm{~mm}$ \\
$\mathrm{~L}_{\text {ground }}$ & $12.5 \mathrm{~mm}$ \\
$\mathrm{~L}_{\mathrm{f}}$ & $13.5 \mathrm{~mm}$ \\
$\mathrm{~W}_{\mathrm{f}}$ & $2.85 \mathrm{~mm}$ \\
$\mathrm{R} 1$ & $3.6 \mathrm{~mm}$ \\
$\mathrm{R} 2$ & $3 \mathrm{~mm}$ \\
$\mathrm{R} 3$ & $2 \mathrm{~mm}$ \\
$\mathrm{~L}$ & $8 \mathrm{~mm}$ \\
$\mathrm{~W}$ & $8 \mathrm{~mm}$ \\
$\mathrm{~d}$ & $4 \mathrm{~mm}$ \\
$\mathrm{e}$ & $2 \mathrm{~mm}$ \\
\hline
\end{tabular}

For better understanding, the following sections explain how the proposed antenna is approached from basic rectangular SWB antenna design to single band notch antenna to finally the double band notch antenna. Post which the metamaterial superstrate is integrated with SWB antenna. 


\section{C.1. Basic Rectangular SWB Antenna Design (Antenna 1)}

The steps of designing the basic SWB antenna (Antenna 1) are shown in Fig. 9. Firstly, a conventional rectangular patch of $15 \times 14.5 \mathrm{~mm}^{2}$ is printed on the FR4 epoxy substrate. The substrate dimensions are $30 \times 35 \mathrm{~mm}^{2}$ with a thickness of $1.5 \mathrm{~mm}$. In the second stage, circular slots are cut from the edges of this patch of radius $2 \mathrm{~mm}$ to increase the bandwidth and for impedance matching. This antenna has been loaded with a rectangular partial ground. The patch is fed by a 50 -ohm microstrip feedline. In the third stage, a novel flower shaped slot has been engraved in radiator to elongate the current path giving resonance at many frequencies. The prototype is optimized using HFSS ' 13 to get the best results. Table III shows the antenna optimized parameters. Fig. 9(c) shows the equivalent circuit diagram of the antenna. The values of the L1, L2, C1, and C2 can be found using the following equations.

$$
\begin{gathered}
L=0.002 l\left[\ln \left(\frac{2 l}{w+t^{\prime}}\right)+0.5+0.2235\left(\frac{w+t^{\prime}}{l}\right)\right] \\
C=\frac{A \varepsilon_{o \varepsilon_{r}}}{d}
\end{gathered}
$$

Where, $\mathrm{L}$ is the inductance, 1 is the length of the feedline/patch, $\mathrm{w}$ is the width line of the feedline/patch, $t^{\prime}$ is the thickness of the copper, $A$ is the overlapping area between the plates, $\varepsilon_{0}$ is the permittivity in vacuum and $\varepsilon_{\mathrm{r}}$ is the relative permittivity of the substrate.

Fig. 10 displays the surface current distribution of the antenna 1 at $3.8 \mathrm{GHz}, 6.4 \mathrm{GHz}, 8.8 \mathrm{GHz}$, and 10.4 GHz. At $3.8 \mathrm{GHz}$, the current concentration is more towards the center of the patch and the feedline. At $6.4 \mathrm{GHz}$, the current is concentrated more towards the feedline, ground and lower edge of the patch. At $8.8 \mathrm{GHz}$ and $10.4 \mathrm{GHz}$, the current is focused towards the feedline and the ground. 


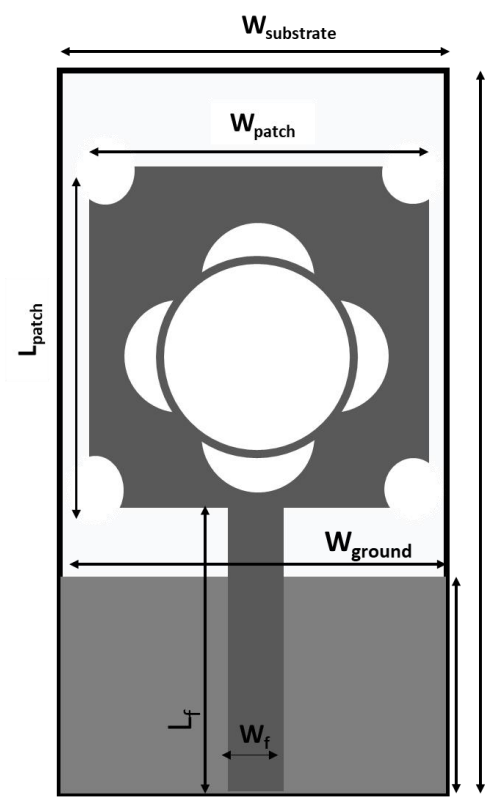

(a)

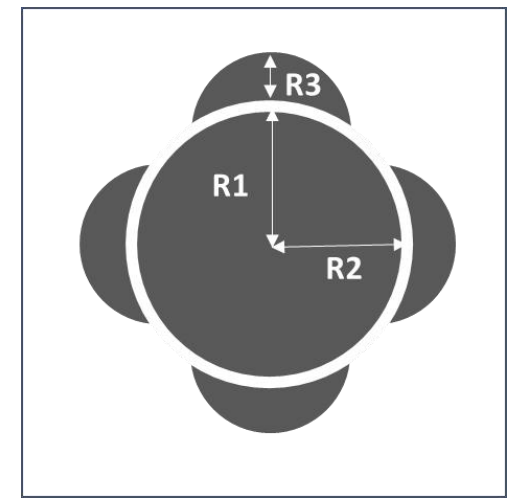

(b)

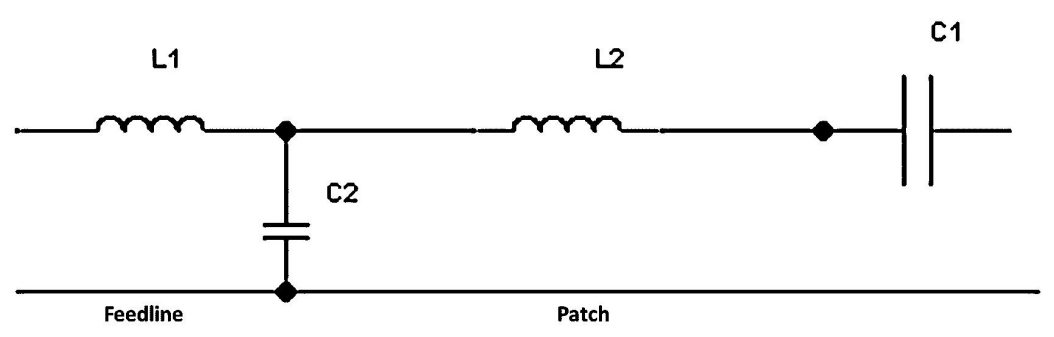

(c)

Fig. 9. (a) Antenna 1, (b) Slot dimensions, (c) Equivalent circuit diagram.

TABLE III. OPTIMIZED DIMENSIONS OF PROPOSED ANTENNA 1

\begin{tabular}{cc}
\hline Parameter & Value \\
\hline $\mathrm{L}_{\text {substrate }}$ & $35 \mathrm{~mm}$ \\
$\mathrm{~W}_{\text {substrate }}$ & $30 \mathrm{~mm}$ \\
$\mathrm{~L}_{\text {patch }}$ & $15 \mathrm{~mm}$ \\
$\mathrm{~W}_{\text {patch }}$ & $14.5 \mathrm{~mm}$ \\
$\mathrm{~W}_{\text {ground }}$ & $30 \mathrm{~mm}$ \\
$\mathrm{~L}_{\text {ground }}$ & $12.5 \mathrm{~mm}$ \\
$\mathrm{~L}_{\mathrm{f}}$ & $13.5 \mathrm{~mm}$ \\
$\mathrm{~W}_{\mathrm{f}}$ & $2.86 \mathrm{~mm}$ \\
$\mathrm{R} 1$ & $3.6 \mathrm{~mm}$ \\
$\mathrm{R} 2$ & $3 \mathrm{~mm}$ \\
$\mathrm{R} 3$ & $2 \mathrm{~mm}$ \\
\hline
\end{tabular}




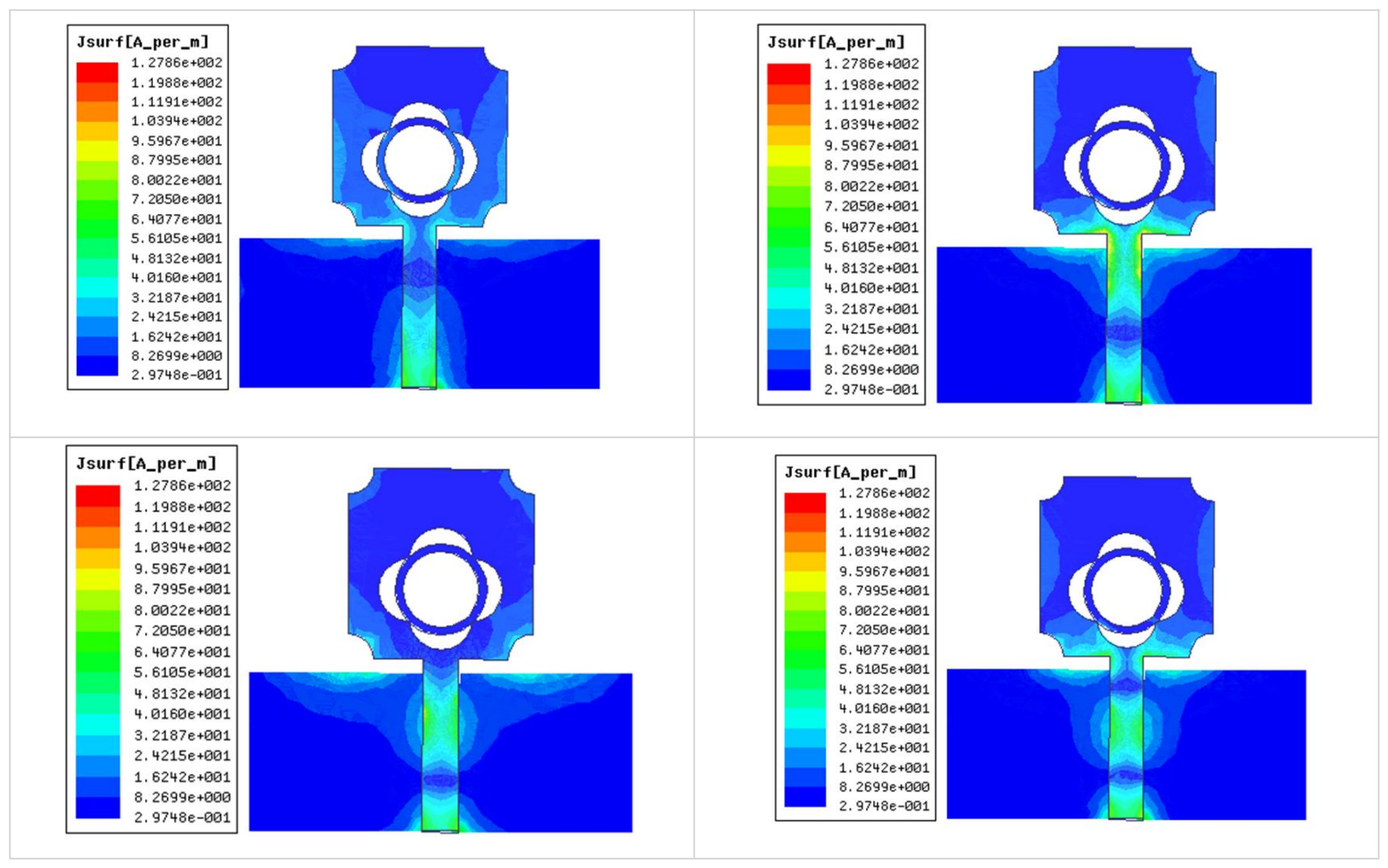

Fig. 10. Current distribution of antenna 1 at the resonating frequencies $3.8 \mathrm{GHz}, 6.4 \mathrm{GHz}, 8.8 \mathrm{GHz}$ and $10.4 \mathrm{GHz}$.

\section{C.2. Single Band notch antenna Formation (Antenna 2)}

To reject the WiMAX and WLAN band, slots are cut on the radiator. Building further on to the prove points explained in this section, the next section focuses on dual-notched SWB antenna. The electromagnetic interference with the WiMAX and WLAN band can be eliminated by using a bandnotched function which has a frequency range of 3.2 -3.6 GHz (WiMAX) and 5.4 -5.6 GHz (WLAN). The surface current concentration is prevailing maximum around the notch at the center frequency and its direction is opposite. This leads to the cancellation of the radiated field, causing high attenuation at the notching frequency band. The band formation technique has been explained below.

Proposed antenna is added with the single notch as described in Fig. 11. U shaped slot, in an inverted manner is implanted on the radiator at the upper side. This results in high impedance at the $f_{\text {notch. }}$ Lslot length is half of the guided wavelength. The following expression is used to find the length of the slot which is cut for suppressing a particular frequency.

$$
\text { fnotch }=\frac{c}{2 L \text { slot } \cdot \sqrt{\varepsilon e f f}}
$$

$F_{\text {notch }}$ is the centre freq of notch band, $\mathrm{c}$ is the speed of light, $\mathrm{L}_{\text {slot }}$ is the length of the slot, and $\varepsilon_{\text {eff }}$ is the effective dielectric constant.

The dimensions of notch are optimized to get the desired notch band. Table IV shows the dimensions of the notch for the $3.5 \mathrm{GHz}$ band. 
TABLE IV. DIMENSIONS OF FIRST NOTCH

\begin{tabular}{cccc}
\hline Parameter & Value & Parameter & Value \\
\hline$\varepsilon_{\text {eff }}$ & 4.4 & $\mathrm{c}$ & $3 \times 10^{8}$ \\
$\mathrm{~F}_{\text {notch }}$ & $3.5 \mathrm{GHz}$ & $\mathrm{W}_{\text {notch1 }}$ & $0.2 \mathrm{~mm}$ \\
$\mathrm{~W}_{\text {notch }}$ & $13 \mathrm{~mm}$ & $\mathrm{~L}_{\text {notch2 }}$ & $6.5 \mathrm{~mm}$ \\
$\mathrm{~L}_{\text {notch1 }}$ & $6.5 \mathrm{~mm}$ & & \\
\hline
\end{tabular}

Slot length is calculated from equation 1 with the desired center frequency of $3.5 \mathrm{GHz}$ for $\mathrm{U}$ slot. Optimized numerical length for the slot is $\mathrm{L}_{\text {slot }}=2 \mathrm{~L}_{\text {notch } 1}+\mathrm{W}_{\text {notch }}=25.2 \mathrm{~mm}$.

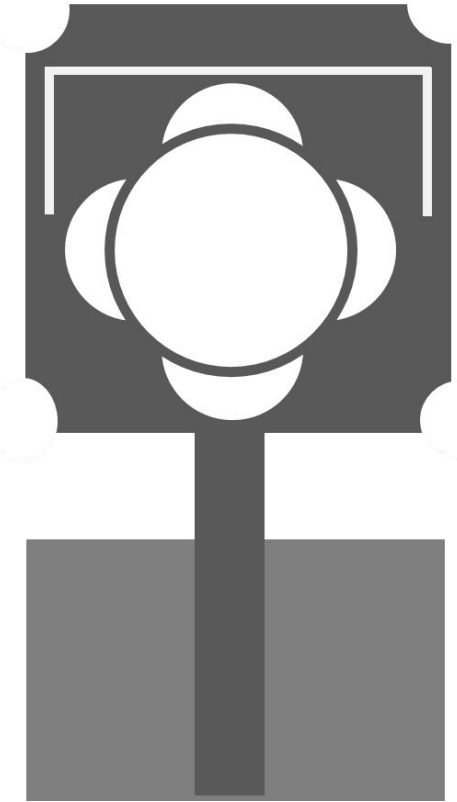

(a)

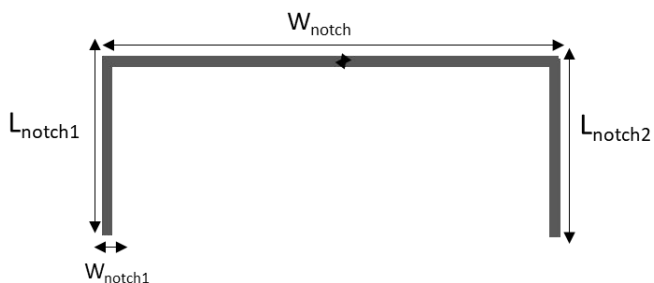

(b)

Fig. 11. (a) Layout of antenna 2, (b) Inverted U-shaped slot.

It is observed that with and without notching the band input impedance of both the antennas is similar, except at $3.5 \mathrm{GHz}$. When the notch is created, there is a mismatch in the value of reactance and resistance leading to suppression at the notched band.

\section{C.3. Double band notch antenna (Antenna 3)}

Finally, the dual band notch antenna is arrived at as described in Fig. 12. The antenna is loaded with another inverted U-shaped notch to reject $5.5 \mathrm{GHz}$ (WLAN). The notch's length is calculated according to equation 1 . The $\mathrm{L}_{\text {slot }}$ calculated according to expression (16) is $15 \mathrm{~mm}$. The width of the slot is $0.7 \mathrm{~mm}$. Table V shows the dimensions of the second notch. 


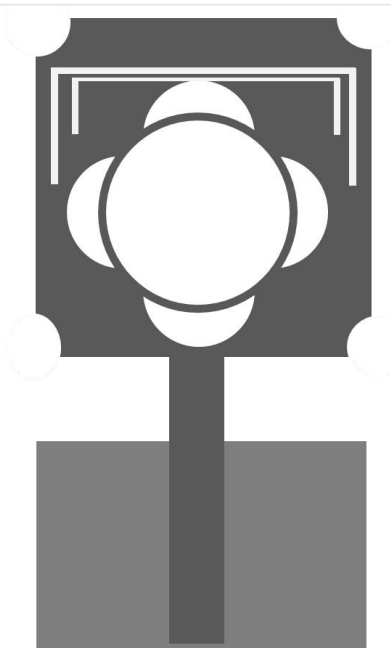

(a)

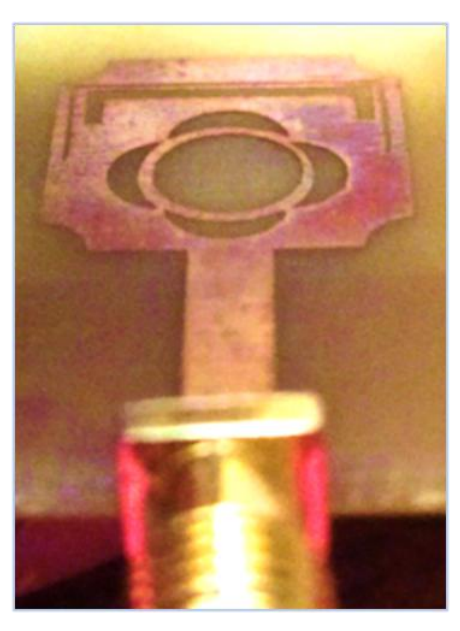

(b)

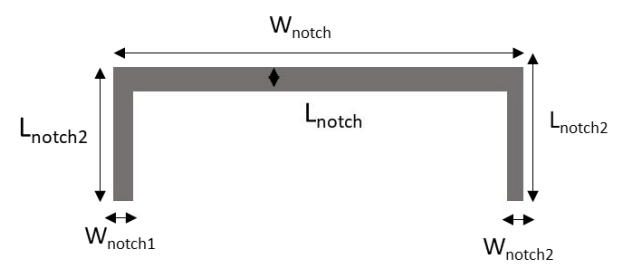

(c)

Fig.12 (a) Layout of Antenna 3, (b) Prototype of Antenna 3, (c) Notch

TABLE V. DimENSIONS OF SECOND NOTCH

\begin{tabular}{cccc}
\hline Parameter & Value & Parameter & Value \\
\hline W notch & $15 \mathrm{~mm}$ & W notch $1=$ W notch 2 & $0.7 \mathrm{~mm}$ \\
L notch & $0.7 \mathrm{~mm}$ & L notch $1=$ L notch 2 & $2.75 \mathrm{~mm}$ \\
\hline
\end{tabular}

\section{C.4. Gain Enhancement using Metamaterial Superstrate (Antenna 4)}

The metamaterial proposed in the above section is attached with Antenna 4, as a superstrate to boost the gain. Fig. 13 shows the top view, array of unit cells and the side view of SWB antenna with metamaterial superstrate. The superstate comprises of array of 9-unit cells in $(3 \times 3)$ rows in the $\mathrm{x}$ and $\mathrm{y}$ direction, printed on the top of the superstrate with no copper layer at the bottom side as shown in Fig. 13 (b). There is a distance of $\lambda / 3$ between the ground of the patch and superstrate. This distance is optimized to get the maximum gain. The superstrate is fixed above the antenna using 4 stands at the corners. The dimensions of the superstrate are kept in such a way that it covers the super wideband antenna radiations completely. The DNG superstrate placed above the SWB antenna, creates a parallel plate capacitance, in between which all the reflections occur. These multiple reflections create in phase electromagnetic field on the aperture. These lead to an improvement in antenna performance like boosting the gain of the antenna. The gain enhancement of up to $65 \%$ is achieved after using metamaterial superstrate with antenna. For validating the performance of the antenna, it has been fabricated. The fabricated SWB antenna with DNG metamaterial superstrate is shown in Fig. 13 (d). 


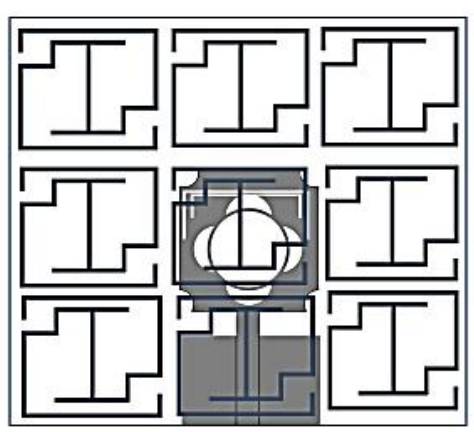

(a)

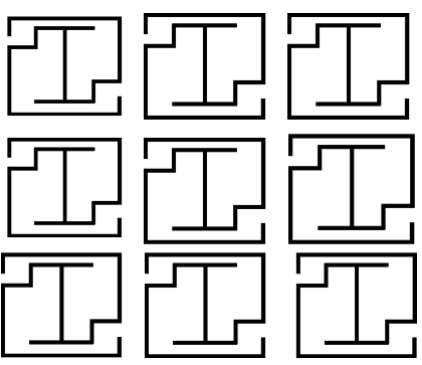

(b)

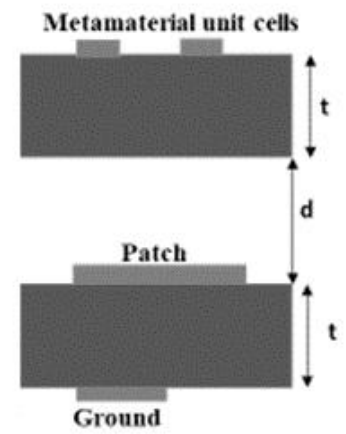

(c)

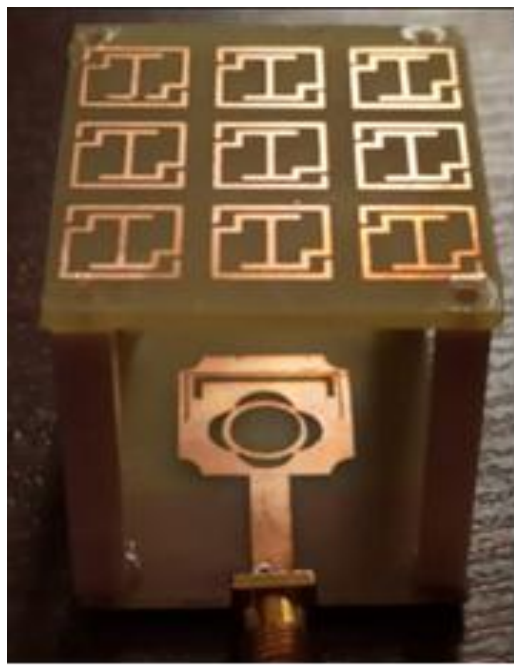

(d)

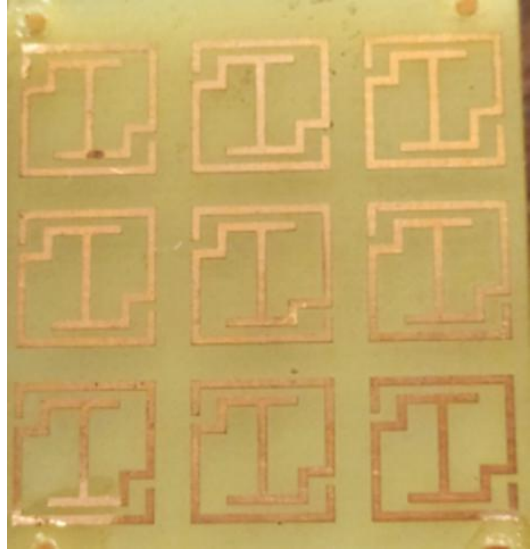

(e)

Fig. 13. (a) Antenna 4 top view, (b) Array of metamaterial unit cells, (c) Geometry of proposed antenna, (d) Prototype of antenna 4, (e)Top view of prototype.

The fabricated antenna with metamaterial array has been tested using Agilent Technologies using the N9918A Field Fox Microwave Network Analyzer.

\section{RESULTS AND DISCUSSION}

\section{A. Simulation Results}

\section{A.1. Impedance characteristics}

The Return loss characteristics of the intermediate steps of the antenna are shown in Fig. 14. There has been an increase in the return loss with the increase in the number of iterations. In the antenna 1, four resonance modes are created which are remarkably close, resulting in a overall bandwidth of 3.1$12 \mathrm{GHz}$. Further,the antenna 1 is integrated with WiMAX and WLAN inverted -U shaped slots. Due to the slotting, there is a mismatch in the value of reactance and resistance leading to suppression at 
Journal of Microwaves, Optoelectronics and Electromagnetic Applications, Vol. 20, No. 2, June 2021 DOI: http://dx.doi.org/10.1590/2179-10742021v20i21147

the notched band. The input impedance of intermediate stages remains the same, except at $3.5 \mathrm{GHz}$ and $5.5 \mathrm{GHz}$. The metamaterial superstrate, when employed above the antenna improved the S11 (dB) of the antenna with no effect on the notch. The improvement in the parameters of the antenna is dependent on the number of metamaterial unit cells as well as the distance between them. Table VI $(\mathrm{d}=32.5)$ and VII $(\mathrm{d}=16 \mathrm{~mm})$ show return loss characteristics comparison of all antennas.

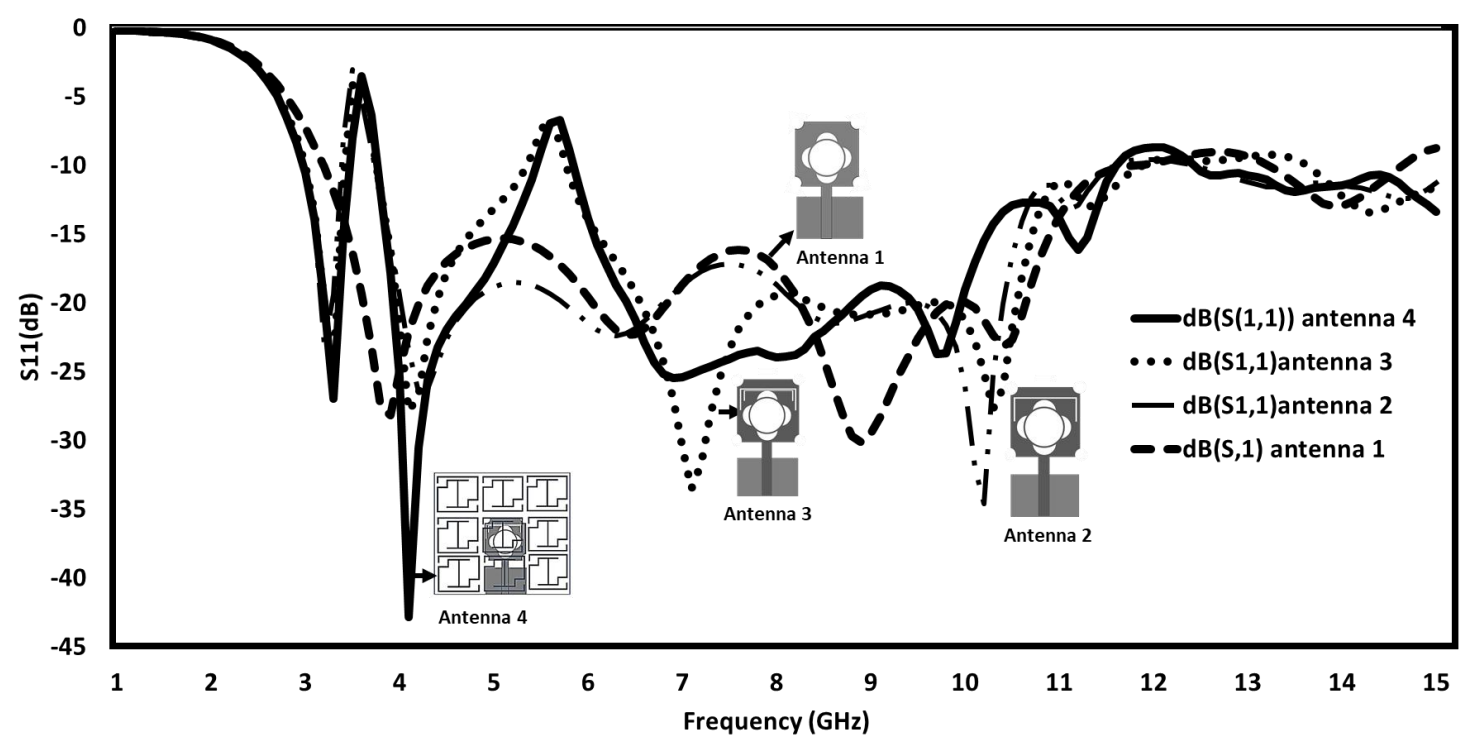

Fig. 14. Return Loss Characteristics of Intermediate stages of proposed antenna.

TABLE VI. RETURN LOSS CHARACTERISTIC COMPARISON AT 4 GHz

\begin{tabular}{ccccccc}
\hline Frequency & d & Antenna & Return loss & $\begin{array}{c}\text { Total BW } \\
(\mathbf{G H z})\end{array}$ & $\begin{array}{c}\text { Radiation } \\
\text { efficiency }\end{array}$ & $\begin{array}{c}\text { Total } \\
\text { Efficiency }\end{array}$ \\
\hline \multirow{2}{*}{$4 \mathrm{GHz}$} & \multirow{2}{*}{$32.5 \mathrm{~mm}$} & Antenna 1 & $-23 \mathrm{~dB}$ & $3.2-11.8$ & $98 \%$ & $98.4 \%$ \\
& & Antenna 2 & $-26 \mathrm{~dB}$ & $3-11.8$ & $97.5 \%$ & $97.6 \%$ \\
& & Antenna 3 & $-26 \mathrm{~dB}$ & $3-11.8$ & $96 \%$ & $97.6 \%$ \\
& Antenna 4 & $-42 \mathrm{~dB}$ & $3-15$ & $100 \%$ & $100 \%$ \\
\hline
\end{tabular}

TABLE VII. RETURN LOSS CHARACTERISTIC COMPARISON AT 8 GHz

\begin{tabular}{ccccccc}
\hline Frequency & $\mathbf{d}$ & Antenna & Return loss & $\begin{array}{c}\text { Total BW } \\
(\mathbf{G H z})\end{array}$ & $\begin{array}{c}\text { Radiation } \\
\text { efficiency }\end{array}$ & $\begin{array}{c}\text { Total } \\
\text { Efficiency }\end{array}$ \\
\hline \multirow{3}{*}{$8 \mathrm{GHz}$} & \multirow{2}{*}{$16 \mathrm{~mm}$} & Antenna 1 & $-23 \mathrm{~dB}$ & $3.2-11.8$ & $97.7 \%$ & $95.8 \%$ \\
& & Antenna 2 & $-26 \mathrm{~dB}$ & $3-11.8$ & $97.7 \%$ & $97 \%$ \\
& & Antenna 3 & $-26 \mathrm{~dB}$ & $3-11.8$ & $97.7 \%$ & $97 \%$ \\
& Antenna 4 & $-42 \mathrm{~dB}$ & $3-15$ & $97.9 \%$ & $97.3 \%$ \\
\hline
\end{tabular}




\section{A.2. Surface current distribution}

The distribution of current in the antenna at the two notched frequencies is shown in Fig. 15 and Fig. 16. At $3.5 \mathrm{GHz}$, most of the current flow near the first inverted U-shaped notch. The direction of the current flowing around the notch is opposite compared to the rest of the patch This opposite direction of the current leads to the cancellation of the radiated field causing suppression at $3.5 \mathrm{GHz}$.

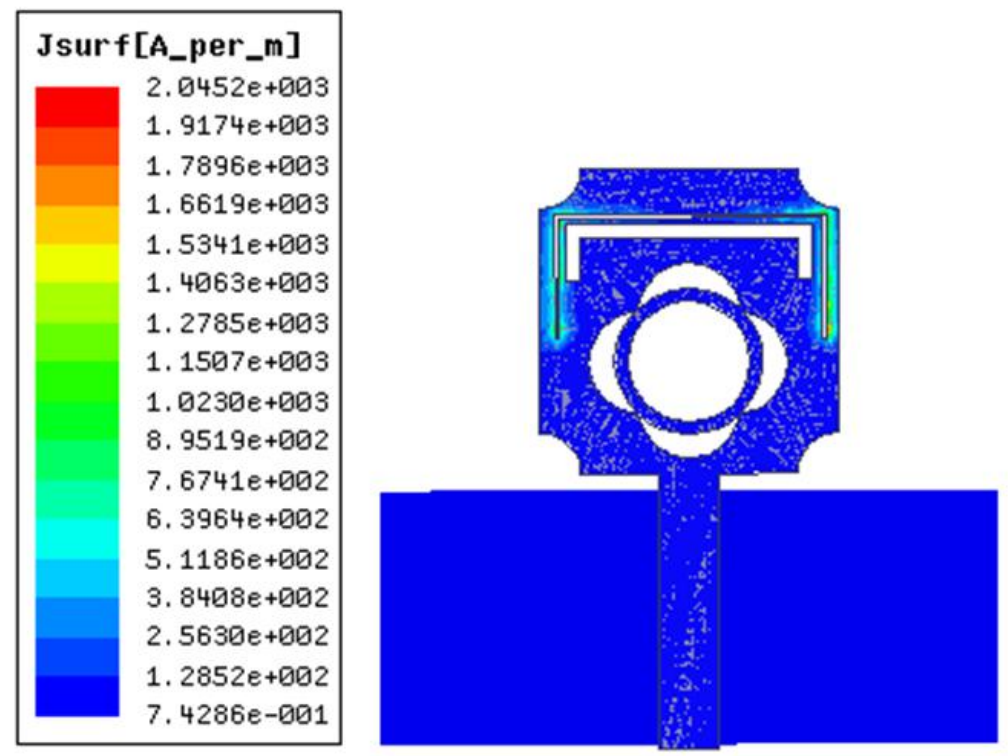

Fig. 15. Surface current distribution at $3.5 \mathrm{GHz}$.

Similarly, the lower inverted U-shaped slot acts as a second notch at $5.5 \mathrm{GHz}$. A very high value of current flowing around the slot and a small current flowing above the slot creates an impedance difference which also leads to attenuation at notched band.

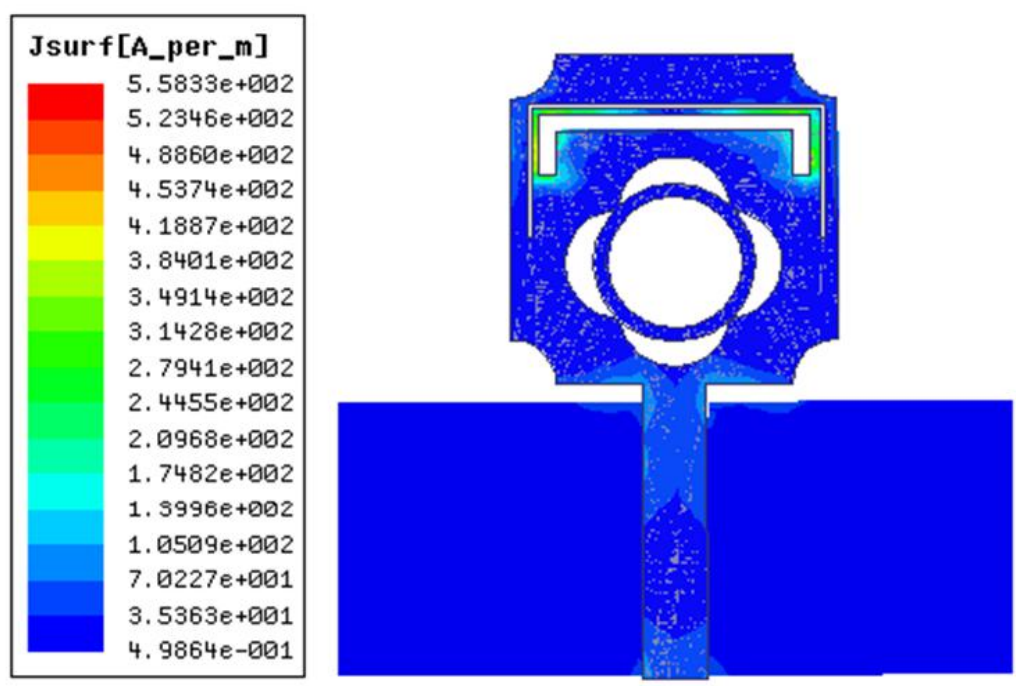

Fig. 16. Surface current distribution $5.5 \mathrm{GHz}$.

\section{A.3. Radiation efficiency}

Fig. 17 shows the radiation efficiency of the proposed antenna in contrast to the other iterations. At $4 \mathrm{GHz}$, antenna 1 has a radiation efficiency of 98 percent, but when the 
metamaterial superstrate is located above the SWB antenna, the efficiency increases to 100 percent (at $\mathrm{d}=32.5 \mathrm{~mm}$ ).

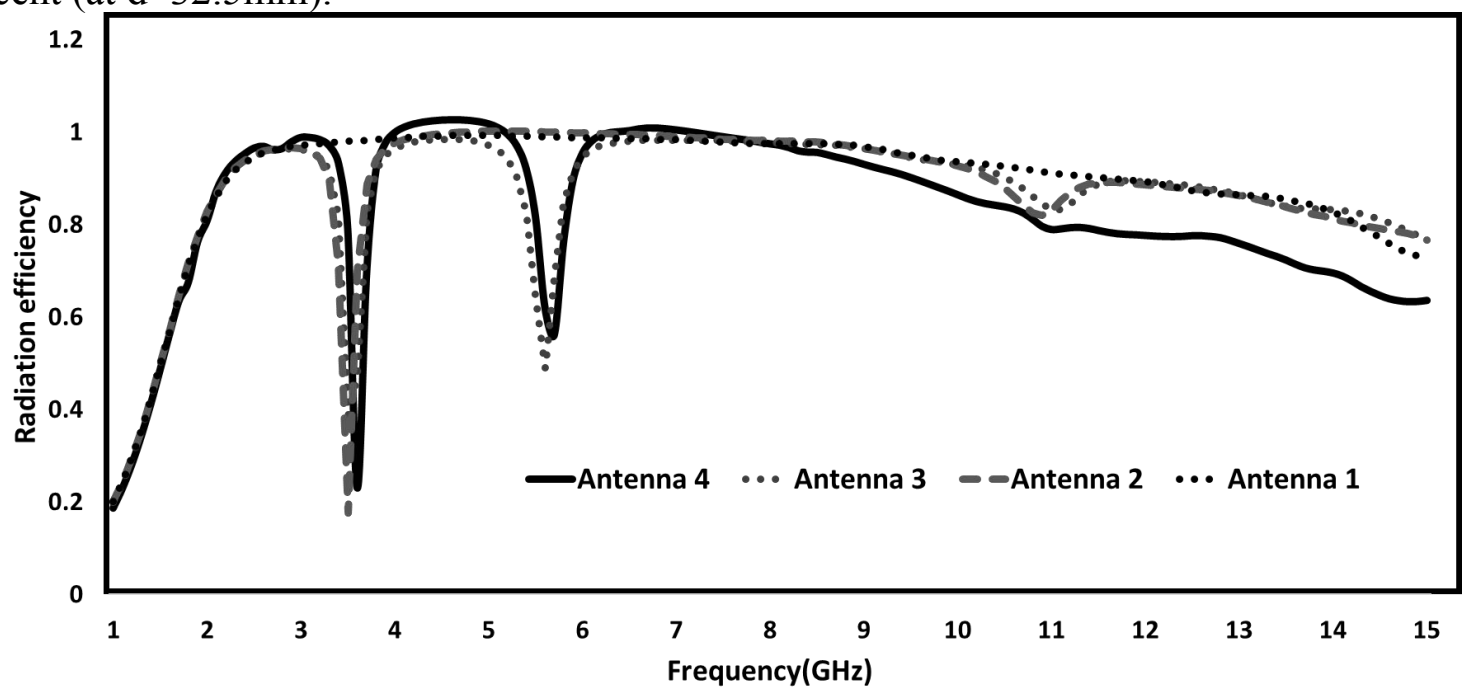

Fig. 17. Radiation efficiency of Antenna 4.

\section{A.4. Total Efficiency}

Fig. 18 shows the overall efficiency of the planned antenna in contrast to the other iterations. At the notched bands, $3.5 \mathrm{GHz}$ and $5.5 \mathrm{GHz}$, efficiency is extremely poor. However, the efficiency for the rest of the band is very good, about $95 \%$ for antenna 1 . There was an improvement in performance when the metamaterial superstrate was mounted (at $\mathrm{d}=32.5 \mathrm{~mm})$.

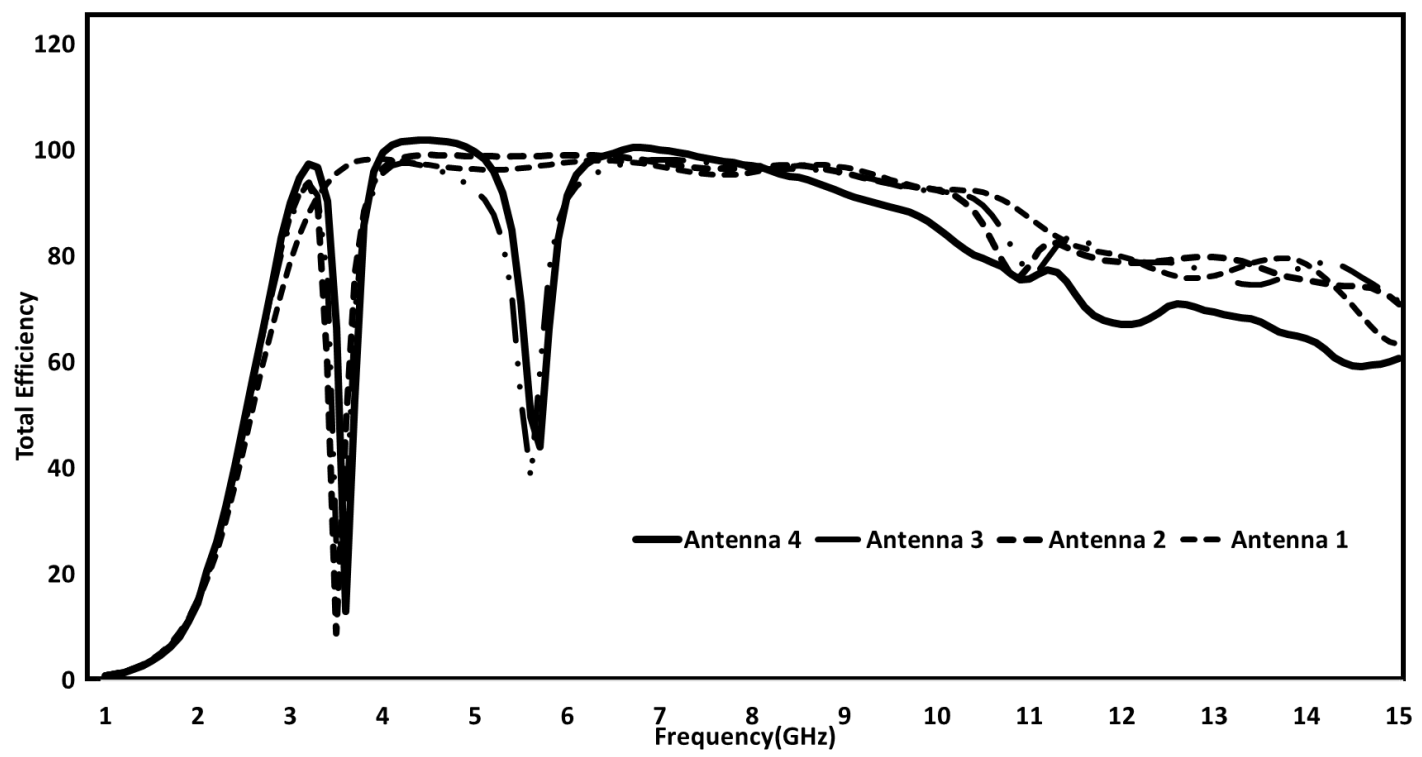

Fig. 18. Radiation efficiency of antenna 4.

\section{A.5. Radiation Characteristics}

The radiation pattern including the 3D polar plot has been examined. The simulated radiation patterns of the SWB antenna with and without metamaterial superstrate for various frequencies such as $4 \mathrm{GHz}$ and $8 \mathrm{GHz}$ at $\mathrm{Phi}=0^{\circ}\left(\mathrm{x}-\mathrm{z}\right.$ plane) and $\mathrm{Phi}=90^{\circ}(\mathrm{y}-\mathrm{z}$ plane) are shown in Fig. 19 and 20. The radiation patterns achieved at both frequencies are omnidirectional. From Fig. 19 and 20, it can be 
observed that there is a little compression in the major lobe of the antenna when metamaterial superstrate is used, making it more directive in a particular direction. The simulated gain values obtained with and without are $4.79 \mathrm{~dB}, 2.84 \mathrm{~dB}$ for $4 \mathrm{GHz}$, when placed at a distance of $32.5 \mathrm{~mm}$ above the patch. The simulated gain values obtained with and without are $5.8 \mathrm{~dB}, 4.9 \mathrm{~dB}$ for $8 \mathrm{GHz}$, when placed at a distance of $18.2 \mathrm{~mm}$ above the patch. There has been a gain enhancement of $65 \%$ after placing the metamaterial superstrate.
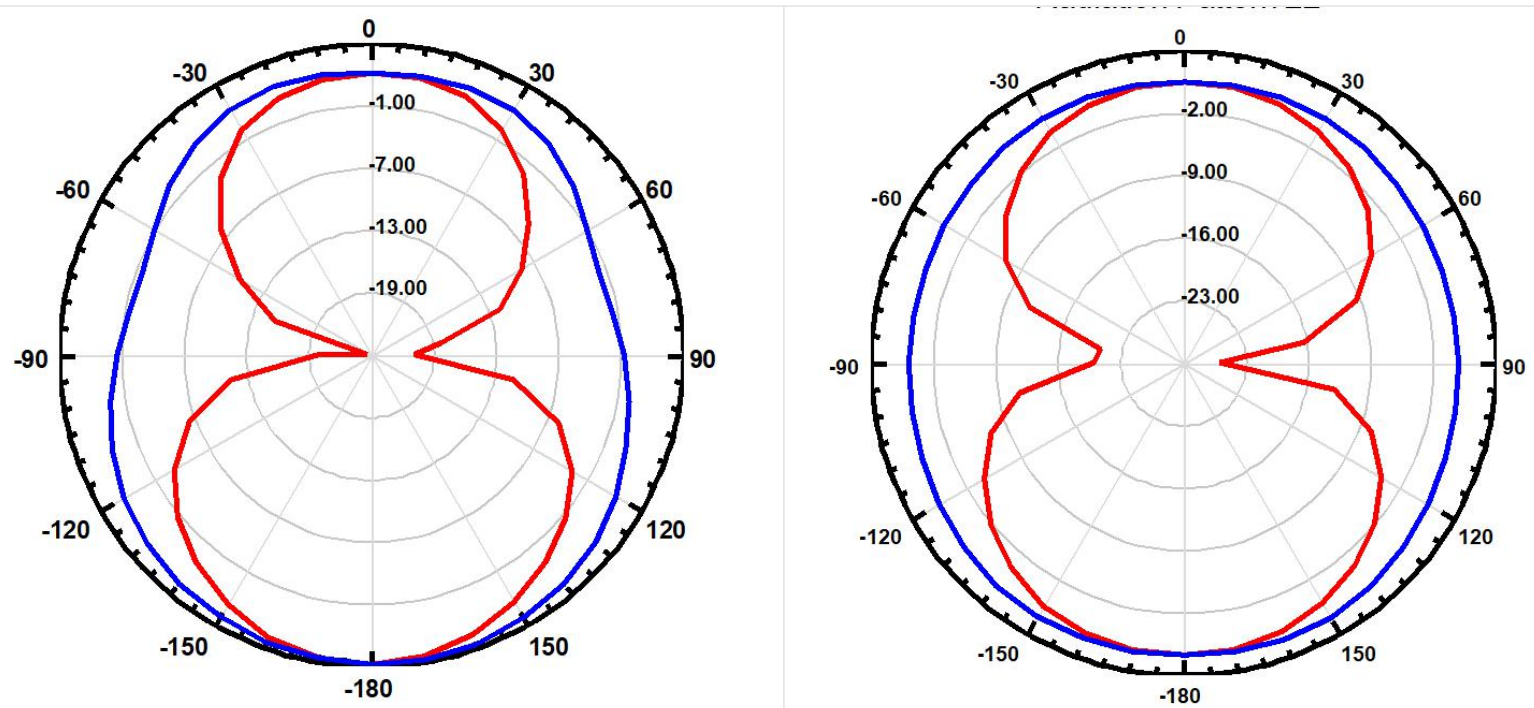

Fig. 19. (a)Radiation pattern with metamaterial in $\mathrm{E}$ and $\mathrm{H}$ plane at $4 \mathrm{GHz}$ when $\mathrm{d}=32.5 \mathrm{~mm}$, (b) Radiation pattern without metamaterial in $\mathrm{E}$ and $\mathrm{H}$ plane at $4 \mathrm{GHz}$.
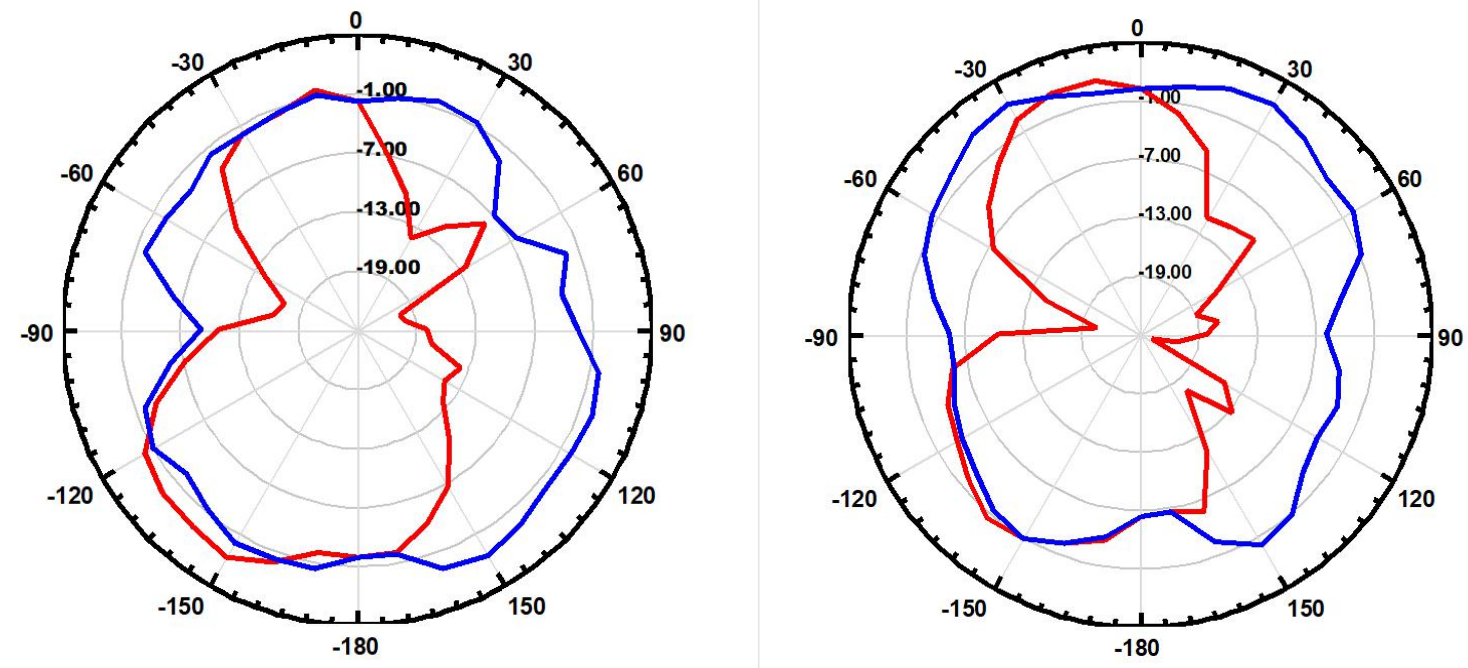

Fig. 20. (a) Radiation pattern with metamaterial in $\mathrm{E}$ and $\mathrm{H}$ plane at $8 \mathrm{GHz}$ when $\mathrm{d}=16 \mathrm{~mm}$, (b) Radiation pattern without metamaterial in $\mathrm{E}$ and $\mathrm{H}$ plane at $8 \mathrm{GHz}$

Fig. 21 and 22 show 3D polar plots of antenna 3 with and without metamaterial superstrate at two 
different frequencies. The main beam of the antenna with metamaterial has compressed when metamaterial superstrate is used, compared to other one. The gain enhancement at $4 \mathrm{GHz}$ when the superstrate is placed at a distance of $33.2(\lambda / 2$ for $4 \mathrm{GHz})$ is $1.95 \mathrm{~dB}$. The gain enhancement at $8 \mathrm{GHz}$ when placed at a distance of $16 \mathrm{~mm}(\lambda / 2$ for $8 \mathrm{GHz})$ from the patch of the antenna is $1.43 \mathrm{~dB}$.
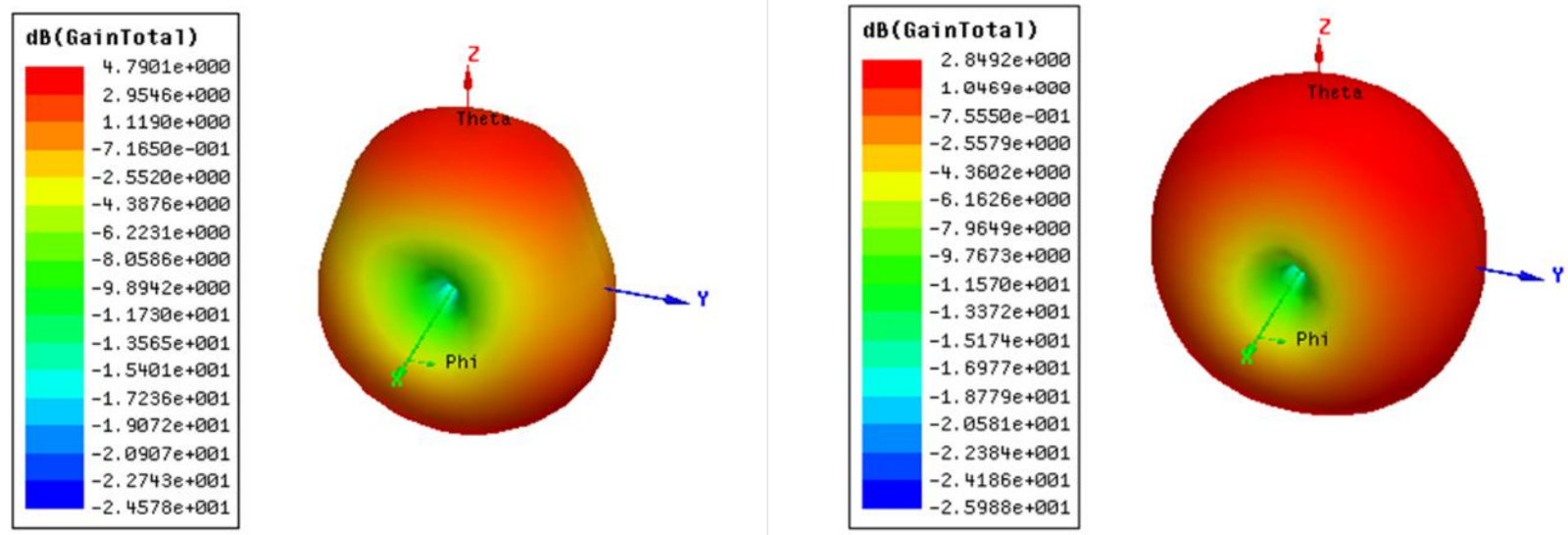

Fig. 21. (a) 3D polar plot with metamaterial at $4 \mathrm{GHz}$ at $\mathrm{d}=32.5 \mathrm{~mm}$, (b)3D polar plot without metamaterial at $4 \mathrm{GHz}$.
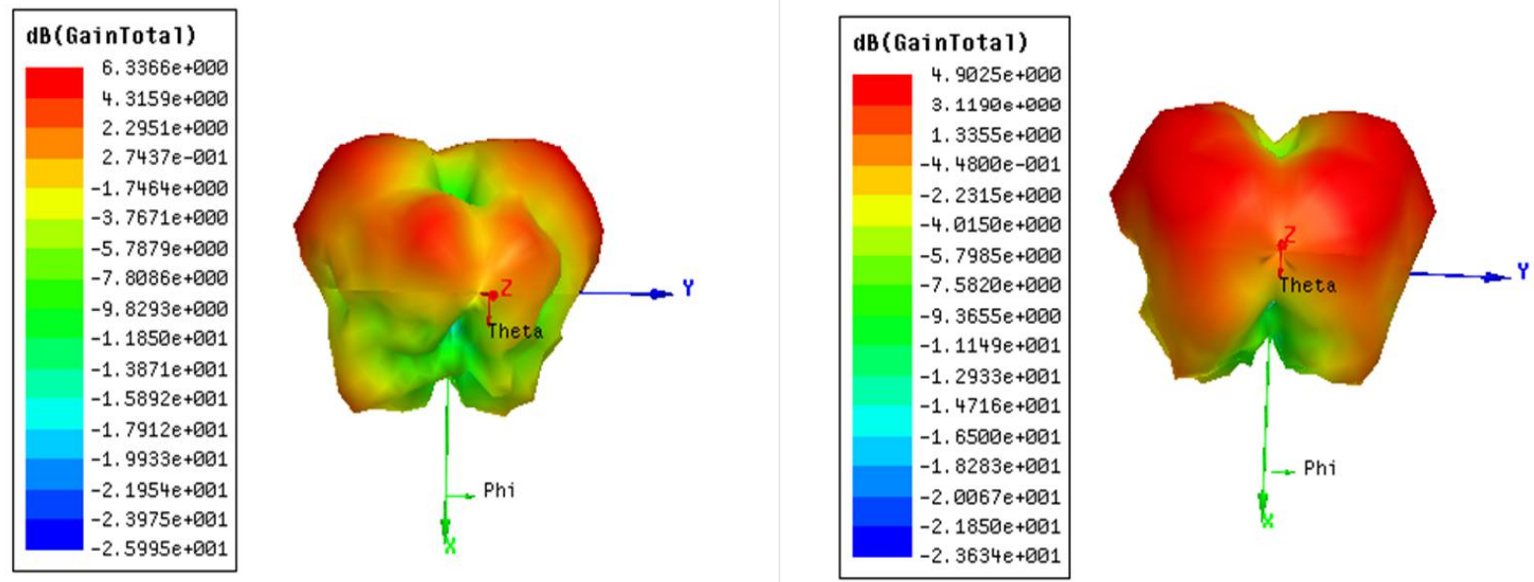

Fig. 22. (a) $3 \mathrm{D}$ polar plot with metamaterial at $8 \mathrm{GHz}$ at $\mathrm{d}=16 \mathrm{~mm}$, (b) $3 \mathrm{D}$ polar plot without metamaterial at $8 \mathrm{GHz}$.

Fig. 23 shows the gain vs frequency for the complete band. Three gain vs frequency curves have been shown for comparison. The gain of unloaded antenna i.e., antenna 3 is shown which has a very low gain value over the complete band of frequency. The metamaterial superstrate layer is placed above antenna 3 to enhance gain. When the value of $d=16 \mathrm{~mm}((\lambda / 2$ 
for $8 \mathrm{GHz}$ ), the gain enhancement is upto $1.43 \mathrm{~dB}$ at $8 \mathrm{GHz}$ and upto $2 \mathrm{~dB}$ can be seen over the entire band. At $\mathrm{d}=32.5 \mathrm{~dB}((\lambda / 2$ for $4 \mathrm{GHz})$, more gain enhancement over the entire band can be seen.

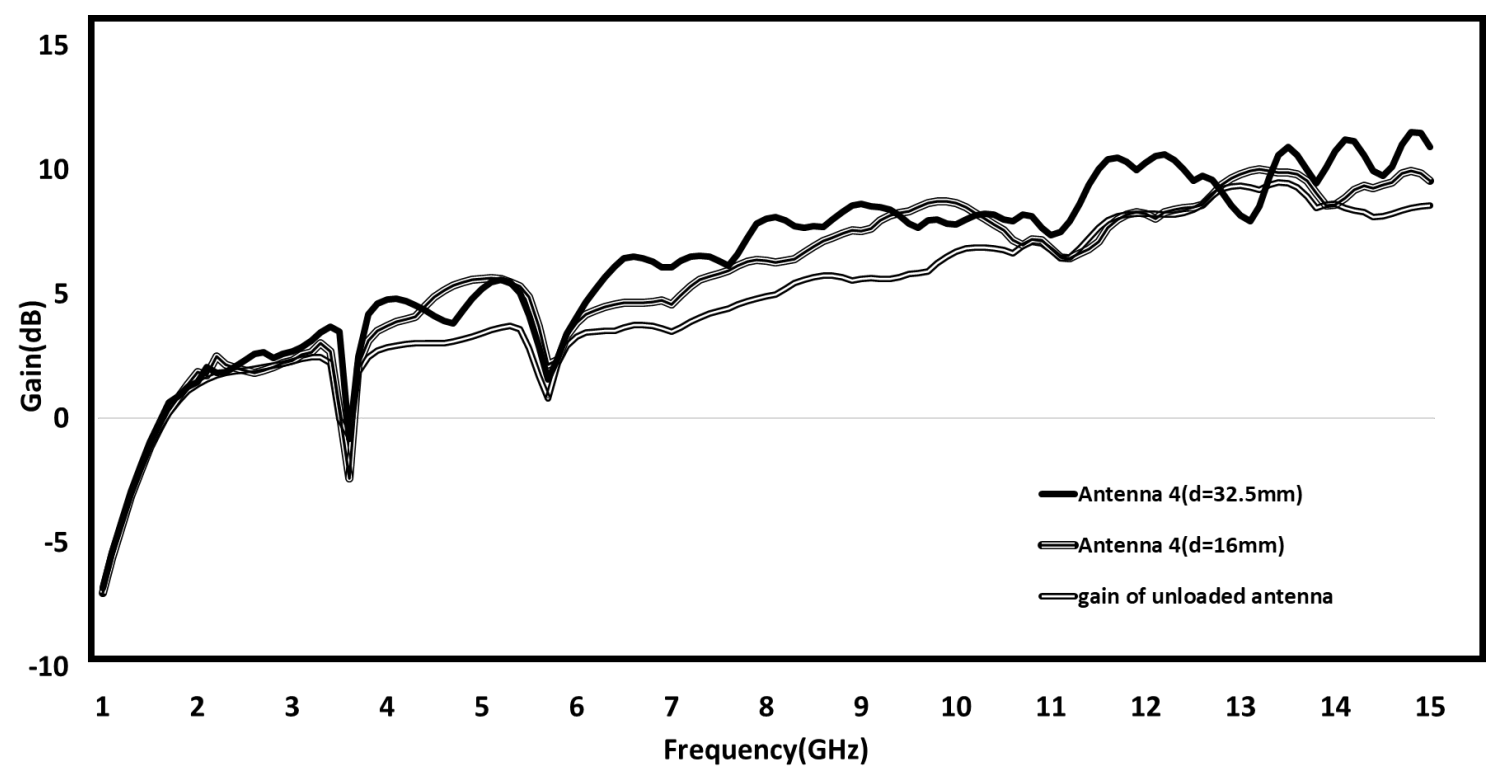

Fig. 23. shows the gain vs frequency.

\section{B. Fabrication and Testing}

The Metamaterial super wideband antenna (Antenna 4) has been fabricated, tested and measured results are presented. Fig. 19(a) shows the fabricated prototype of SWB antenna. The measurement is done by Agilent Technologies using the N9918A Field Fox Microwave Network Analyzer and the complete setup is shown in Fig. 24. The experimental and simulated results are in line with each other.

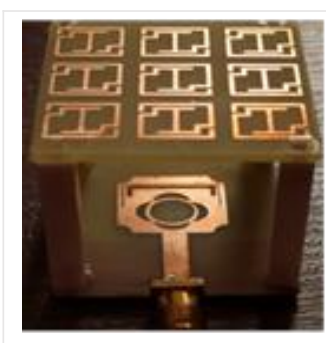

(a)

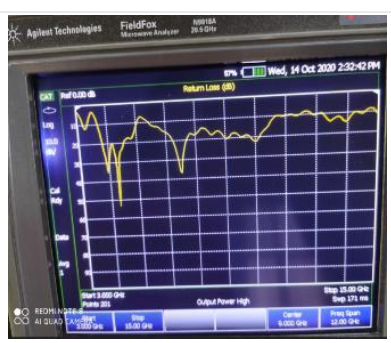

(b)

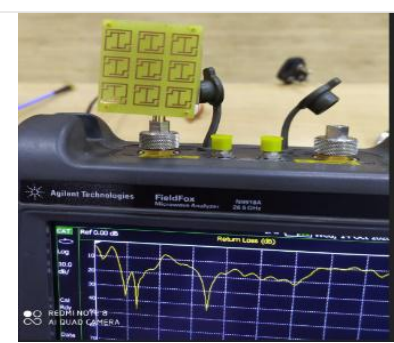

(c)

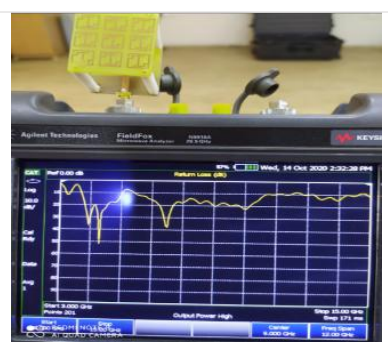

(d)

Fig.24 (a) Fabricated SWB antenna, (b) Return loss characteristics in VNA, (c) Top view of antenna connected to VNA, (d) Sideview of fabricated antenna.

Fig. 25 contrasts the return loss attribute of measured and simulated results of Antenna 4. A very good impedance matching can be seen in the super wide band frequency range 3-15 GHz except at notched band 3.3-3.5 GHz and 5.4-5.6 GHz.The wide bandwidth requirement for SWB application is fulfilled, and band notching at WiMAX and WLAN is achieved in order to avoid interference. 


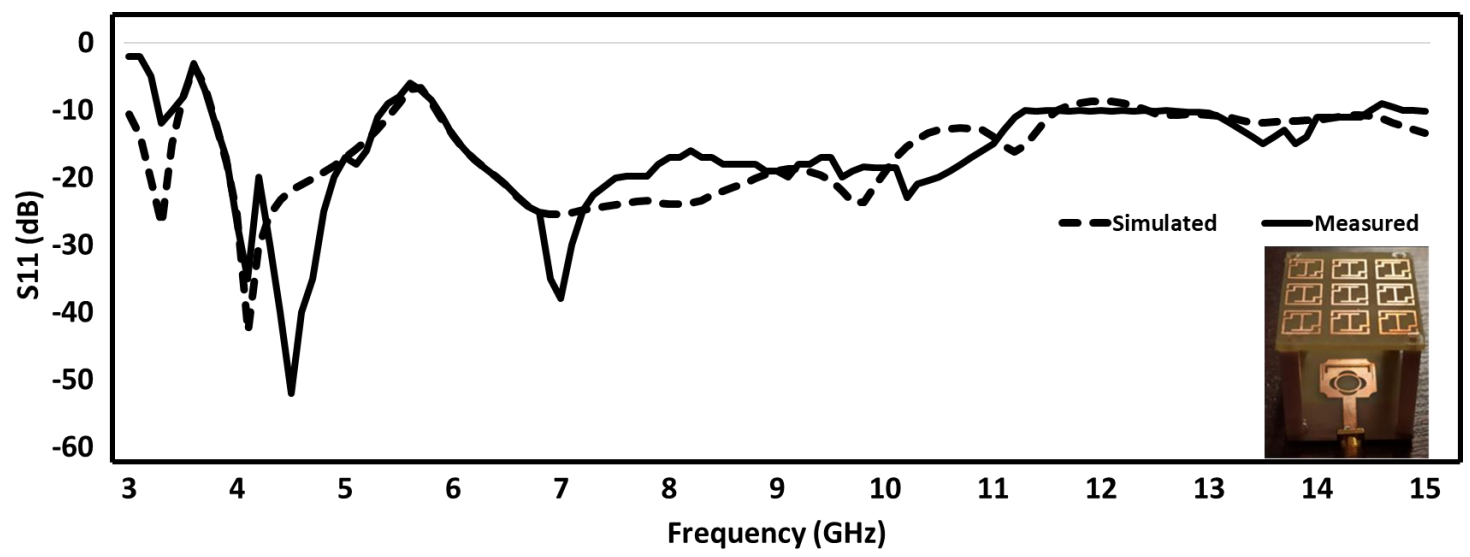

Fig. 25. Comparison of experimental and simulated results of proposed antenna.

Table VII demonstrates the comparison of Antenna 4 with similar types of antennas in the wideband range. Also, when the proposed is compared with similar antennas, it is found to be compact with just one layer of the metamaterial. In [30], the size of the antenna was $40 \times 30 \mathrm{~mm}$ which is comparatively large, with a small bandwidth of 8-12 GHz. In [31], an antenna of $60 \times 60 \mathrm{~mm}$ was designed for 10 $\mathrm{GHz}$ and three layers of metamaterials are used to boost the gain of the designed antenna. In [32], an antenna was designed with the size of $60 \times 50 \mathrm{~mm}$, and a metamaterial superstrate was placed above the patch to enhance gain by $7.65 \mathrm{~dB}$. In our proposed antenna, there is a gain enhancement of the antenna by $65 \%$ and a high bandwidth of $3-15 \mathrm{GHz}$ is obtained.

TABLE VIII. COMPARISON OF THE PROPOSED METAMATERIAL BASED ANTENNA WITH THE EXISTING ANTENNAS

\begin{tabular}{cccccccc}
\hline References & $\begin{array}{c}\text { Substrate } \\
\text { Type }\end{array}$ & Thickness & $\begin{array}{c}\text { Size of the } \\
\text { substrate }\end{array}$ & BW & $\begin{array}{c}\text { Layers of } \\
\text { metamaterial } \\
\text { used }\end{array}$ & $\begin{array}{c}\text { Peak } \\
\text { Gain }\end{array}$ & $\begin{array}{c}\text { Radiation } \\
\text { Efficiency }\end{array}$ \\
\hline$[30]$ & $\begin{array}{c}\text { Rogers } \\
4003 \mathrm{C}\end{array}$ & $0.8 \mathrm{~mm}$ & $40 \times 30 \mathrm{~mm}$ & $8-12 \mathrm{GHz}$ & 1 & $7.71 \mathrm{~dB}$ & $85 \%$ \\
{$[31]$} & $\begin{array}{c}\text { Rogers } \\
\text { 4003 }\end{array}$ & $0.8 \mathrm{~mm}$ & $62 \times 62 \mathrm{~mm}$ & $10 \mathrm{GHz}$ & 3 & $11.9 \mathrm{~dB}$ & - \\
$\begin{array}{c}{[32]} \\
\begin{array}{c}\text { Proposed } \\
\text { antenna }\end{array}\end{array}$ & FR4 & $1.6 \mathrm{~mm}$ & $60 \times 50 \mathrm{~mm}$ & $5.2 \mathrm{GHz}$ & 2 & $8.26 \mathrm{~dB}$ & - \\
\hline
\end{tabular}

\section{CONCLUSIONS}

A metamaterial based high gain super wideband antenna with the double notched band is designed and analyzed. The parametric studies of inverted U-shaped slots which are responsible for the notch are carried out to optimize the notch characteristics at WiMAX and WLAN bands. A $3 \times 3$ array of metamaterial unit cells is loaded as the superstrate. The proposed antenna is seen to boost the gain characteristics. The fabricated and simulated antenna results are seen to have a good agreement with each other. This antenna can be put to use for wireless applications. 


\section{REFERENCES}

[1] Federal Communication Commission Washington, "Federal communication commission revision of part 15 of the commission's rules regarding UWB transmission system from 3.1-10.6 GHz", DC ET-Docket, pp. 98-153, 2002.

[2] M. L. Meena and A. Gupta, "Design analysis of a semi-circular floral shaped directional UWB antenna integrated with wireless multiband applications", PIERS C, vol. 90, pp. 155-167, March 2019.

[3] J. R. Verbiest, and G. A. E. Vandenbosch, "A novel small size printed tapered monopole antenna for UWB WBAN", IEEE Antennas Wireless Propagation Letters, vol. 5, pp. 377-379, September 2006.

[4] G. Krishna, D. D. Krishna, C. K. Anandan, P. Monahan and K. Vasudevan, "Design of a compact semi elliptical monopole slot antenna for UWB system", IEEE Transactions Antennas Propagation, vol. 57, pp. 1834-1837, July 2009.

[5] N. T. Sagar, M. L. Meena, and P. Shukla, "Design and performance analysis of a UWB circular ring antenna with defected ground structure”, ICTACT International Journal on Communication Technology, vol. 8, pp. 1656-1663, February 2017.

[6] N M.. Awad and M. K. Abdelaziz, "Multislot microstrip antenna for ultrawideband application”, Journal of king Saud University Engineering Science, vol. 30, pp. 38-45, December 2018.

[7] M. M. S. Taheri, H. R. Hasaini and M. A. Nezhad, "UWB printed slot antenna with Bluetooth and dual notch bands", IEEE Antennas Wireless Propagation Letters, vol. 10, pp. 255-258, February 2011.

[8] H. S. Mewara, D. Jhanwar, M. M. Sharma and J. K. Deegwal, "A printed monopole ellipsoidal UWB antenna with four band rejection characteristics", International Journal of Electronics and Communication, vol. 83, pp. 222-232, August 2017.

[9] X. F. Zhu and D. L. Su, "Symmetric E shaped slot for UWB antenna with band notched characteristics", Microwave and Optical Letters, vol. 52, pp. 1594-1597, April 2010.

[10] M. M. Sharma, J. K. Deegwal, A. Kumar and M. C. Govil, "Compact planar monopole antenna with quadruple band notched characteristics", Progress in Electromagnetics Research, vol. 47, pp. 29-36, January 2014.

[11] H. A. Mohamed, A. S. Elkorany, S. A. Saad and D. A. Saleeb, "New Simple flower shaped reconfigurable band notched UWB antenna using single varactor diode", Progress in Electromagnetics Research C, vol. 76, pp. 197-206, January 2017.

[12] C.-C. Lin, P. Jinn and R. Ziolkowski, "Single, Dual and triband notched Ultrawideband Antennas using capacitively loaded loop Resonators", IEEE Transactions on Antennas and Propagation, vol. 60, pp. 102-109, January 2011.

[13] M. C.Tang, H. Wang, T. Deng and R.W. Ziolkowski, "Compact planar Ultrawideband antennas with continuous ly tunable, independent band-notched filters", IEEE Transaction Antennas Propagation, vol. 64, pp. 3292-3301, August 2016.

[14] N. Nemati and M. Bemani, "A novel reconfigurable microstrip fractal UWB antenna with six variable rejection frequency bands”, International Journal of Microwave and Wireless Technologies, vol. 12, pp. 148-154, August 2019.

[15] S. Mandal, A. Karmakar, H. Singh, S. K. Mandal, R. Mahapatra and A. K. Mal, "A miniaturized CPW fed on chip UWB monopole antenna with band notch characteristics", International Journal of Microwave and Wireless Technologies, vol. 12, pp. 95-102, July 2019.

[16] Alexa Poulos N. G. and Jackson D. R., "Fundamental Superstrate effects on the printed circuit antennas", IEEE Transactions Antennas Propagation, vol. 32, pp. 807-816, August 1984.

[17] A. Foroozesh and L. Shafai, "Investigation into the effects of the patch type FSS superstrate on the high gain cavity resonance antenna design", IEEE Transaction Antennas Propagation, vol. 58, pp. 258-270, February 2010.

[18] U. Patel and T. Upadhaya, "Design and analysis of mu negative material loaded wideband electrically compact antenna for WLAN/WiMAX applications", Progress in Electromagnetics Research M, vol. 79, pp. 11-22, February 2019.

[19] R. K. Saraswat and M. Kumar, "Miniaturized slotted ground UWB antenna loaded with metamaterial for WLAN and WiMAX applications", in Progress in Electromagnetics Research B, vol. 65, pp. 65-80, January 2016.

[20] Y. Yang, , Y. Z. Yin, Y. Q. Wei, B. W. Liu and A. F. Sun, "A circular wide-slot antenna with dual band notched characteristics for UWB applications", Progress in Electromagnetics Research Letters, vol. 23, pp. 137-145, May 2011.

[21] Y. Z. Cai, H. C. Yang and L. Y. Cai, "Wideband monopole antenna with three band notched characteristics", IEEE Transactions on Antennas and Propagation Letters, vol. 13, pp. 607-610, March 2014.

[22] H. Liu, C. Yin and Y. Huang, "Design of smiling face shaped band notched UWB antenna", Transaction on Electrical and Electronic Engineering, vol.12, pp. 312-316, January 2017.

[23] S. Barbarino and F. Consol, "UWB circular slot antenna provided with an inverted L notch filter for 5GHz WLAN band", IEEE Transactions on Antennas and Propagation, vol. 104, pp. 1-13, May 2010.

[24] M. Saravanan, V. Beslin Geo and S. M. Umarani, "Gain enhancement of patch antenna integrated with metamaterial inspired superstrate", Journal of Electrical Systems and Information Technology, vol. 52, pp. 263-270, December 2018.

[25] D. R. Smith, D.C. Vier, Th. Koschny and C. M. Soukoulis, "Electromagnetic Parameter Retrieval from Inhomogeneous Metamaterials", Physics Review E, vol. 71, pp. 036617, March 2005.

[26] Md. M. Hasan, M. R. I. Faruque and M. T. Islam, "Improved square Z shaped DNG meta-atom for C-and X band applications", Current Science, vol. 114, pp. 2514-2518, June 2018.

[27] A. F. Almutairi, M. Shahidul, M. Samsuzzaman, M. T. Islam, N. Misran and M.T.1 Islam, "A Complementary split ring resonator-based metamaterial with effective medium ratio for c band microwave applications", Results in Physics, vol. 15, pp. 102675, December 2019.

[28] T. Ali, R. C. Birder, "A Miniaturized Volkswagen Logo UWB antenna with slotted ground structure and metamaterial for GPS, WiMAX, and WLAN applications”, Progress in Electromagnetics Research, vol.72, pp. 29-41, February 2017.

[29] C. L. Ruan, L. Peng, "UWB band notched monopole antenna design using electromagnetic band gap structures", IEEE Transaction Antennas Propagation, vol. 59, pp.1074-1081, March 2011. 
Journal of Microwaves, Optoelectronics and Electromagnetic Applications, Vol. 20, No. 2, June 2021 DOI: http://dx.doi.org/10.1590/2179-10742021v20i21147

[30] O. Borazjani, M. N.-Moghadasi, J. R.-Mohassel and R. A. Sadeghzadeh, "Bandwidth improvement of planar antennas using single layer metamaterial substrate f or $\mathrm{x}$ band applications", International Journal of Microwave and Wireless Technologies, vol. 12, no. 9, pp. 906-914, April 2020.

[31] D. Li, Z. Szabo, X. Qing, E. P. Li and Z. N. Chen, "A High Gain Antenna with an optimized Metamaterial Inspired Superstrate", in IEEE transactions on Antennas and Propagation, vol. 60, no. 12, pp. 6018-6023, Dec. 2012.

[32] H. Suthar, D. Sarkar, K. Saurav and K. V. Srivastava, "Gain enhancement of microstrip patch antenna using near-zero index metamaterial (NZIM) lens", 2015 Twenty First National Conference on Communications (NCC), Mumbai, pp.1-6, April 2015.

[33] A. K. Singh, M. P. Abegaonkar and S. K. Koul, "High Gain and High Aperture Efficiency Cavity Resonator Antenna Using Metamaterial Superstrate”, IEEE Antennas and Wireless Propagation Letters, vol. 16, pp. 2388 - 2391, June 2017.

[34] S. Chaimool, K. L. Chung, and P. Akkaraekthalin, "Bandwidth and gain enhancement of microstrip patch antennas using reflective metasurface", IEICE transactions on communications, vol.10, pp. 2496-2503, October 2010.

[35] H. Liu, S. Lei, X. Shi, and L. Li, "Study of Antenna Superstrates Using Metamaterials for Directivity Enhancement Based on Fabry-Perot Resonant Cavity", International Journal of Antennas and Propagation, vol. 2013, February 2013. 